\title{
SOEP
}

SOEPpapers

SOEPpapers
on Multidisciplinary Panel Data Research

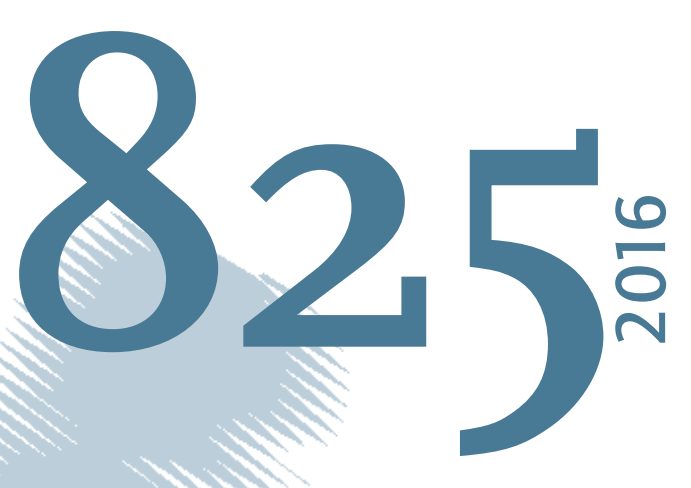

\section{Work Hour Mismatch and Job Mobility: Adjustment Channels and Resolution Rates}

Michael C. Knaus and Steffen Otterbach 
This series presents research findings based either directly on data from the German SocioEconomic Panel study (SOEP) or using SOEP data as part of an internationally comparable data set (e.g. CNEF, ECHP, LIS, LWS, CHER/PACO). SOEP is a truly multidisciplinary household panel study covering a wide range of social and behavioral sciences: economics, sociology, psychology, survey methodology, econometrics and applied statistics, educational science, political science, public health, behavioral genetics, demography, geography, and sport science.

The decision to publish a submission in SOEPpapers is made by a board of editors chosen by the DIW Berlin to represent the wide range of disciplines covered by SOEP. There is no external referee process and papers are either accepted or rejected without revision. Papers appear in this series as works in progress and may also appear elsewhere. They often represent preliminary studies and are circulated to encourage discussion. Citation of such a paper should account for its provisional character. A revised version may be requested from the author directly.

Any opinions expressed in this series are those of the author(s) and not those of DIW Berlin. Research disseminated by DIW Berlin may include views on public policy issues, but the institute itself takes no institutional policy positions.

The SOEPpapers are available at http://www.diw.de/soeppapers

\section{Editors:}

Jan Goebel (Spatial Economics)

Martin Kroh (Political Science, Survey Methodology)

Carsten Schröder (Public Economics)

Jürgen Schupp (Sociology)

Conchita D'Ambrosio (Public Economics, DIW Research Fellow)

Denis Gerstorf (Psychology, DIW Research Director)

Elke Holst (Gender Studies, DIW Research Director)

Frauke Kreuter (Survey Methodology, DIW Research Fellow)

Frieder R. Lang (Psychology, DIW Research Fellow)

Jörg-Peter Schräpler (Survey Methodology, DIW Research Fellow)

Thomas Siedler (Empirical Economics)

C. Katharina Spieß ( Education and Family Economics)

Gert G. Wagner (Social Sciences)

ISSN: 1864-6689 (online)

German Socio-Economic Panel (SOEP)

DIW Berlin

Mohrenstrasse 58

10117 Berlin, Germany

Contact: Uta Rahmann | soeppapers@diw.de

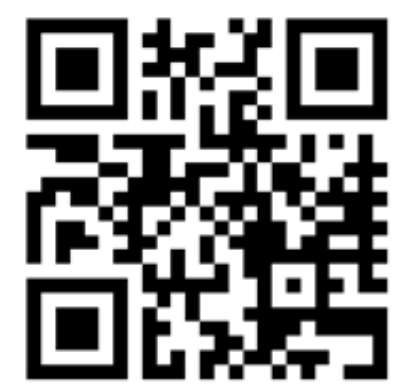




\title{
Work Hour Mismatch and Job Mobility: Adjustment Channels and Resolution Rates
}

\author{
MiCHAEL C. KNAUS ${ }^{+}$ \\ University of St. Gallen
}

\author{
STEFFEN OTTERBACH* \\ University of Hohenheim \\ and \\ Institute for the Study of Labor (IZA)
}

January 2016

\begin{abstract}
This paper analyses the role of job changes in overcoming work hour constraints and the work hour mismatches resulting from these constraints (i.e., differences between actual and desired work hours). Building on previous findings that job change increases the flexibility of actual work hours, the study addresses two as yet neglected questions in the context: (i) How do changes in desired work hours, in addition to changes in actual work hours, contribute to the resolution of these mismatches? (ii) Does the increased flexibility help actually to resolve work hour mismatches? We exploit information about the magnitude of the prevailing mismatch to improve both the credibility and interpretation of the results. We find that job change increases the probability of resolving work hour mismatches, but far less than expected with free choice of hours across jobs. Instead, large fractions of workers either stay or switch into overemployment. We thoroughly investigate the robustness and heterogeneity of our results.
\end{abstract}

JEL Codes: J21, J22

Keywords: Work Hour Constraints, Work Hour Mismatch, Job Mobility, Desired Work Hours, Germany

\footnotetext{
+ Corresponding author: University of St. Gallen, Swiss Institute for Empirical Economic Research, Varnbüelstrasse 14, CH-9000 St. Gallen, Switzerland.

* University of Hohenheim, Institute for Health Care \& Public Management, Fruwirthstr. 48, D-70599 Stuttgart, Germany.

The data used in this publication were made available by the German Socio-Economic Panel Study at the German Institute for Economic Research (DIW), Berlin. This study was presented at the $29^{\text {th }}$ conference of the European Society of Population Economics (ESPE) in Izmir, Turkey, the internal research seminar at the University of St. Gallen, and the research seminar at the Melbourne Institute of Applied Economic and Social Research. The authors would also like to thank the seminar and conference participants as well as Richard Blundell, Michael Lechner, Aderonke Osikominu, Arthur van Soest, Alfonso Sousa-Poza, and Mark Wooden for valuable commentary and discussion.
} 


\section{Introduction}

The literature on labor supply has developed a variety of models that differ in their treatment of dynamics, savings, households, human capital, and other aspects (Keane, 2011). Regardless of the specific optimization problem, most models assume that workers are able to supply their optimal number of work hours. However, the assumption of free hours choice stands in stark contrast to the substantial work hour mismatch (i.e., over- or underemployment) that is frequently reported worldwide (Otterbach, 2010). ${ }^{1}$ The presence of work hour mismatch is in line with the literature on work hour constraints. Such constraints could prevent workers from realizing their optimal number of work hours and have been discussed since the seminal work of Altonji and Paxson (1986, 1988). ${ }^{2}$ A growing strand of literature investigates the consequences of the resulting work hour mismatches. These studies suggest adverse effects on health, as well as on life and job satisfaction (Bassanini \& Caroli, 2015; Bell, Otterbach, \& Sousa-Poza, 2012; Kugler, Wiencierz, \& Wunder, 2014; Wooden, Warren, \& Drago, 2009).

Recently, the importance of hours constraints in the labor market has been emphasized in the influential paper of Chetty, Friedmann, Olsen and Pistaferri (2011). They show that work hour constraints and adjustment costs can explain the lack of bunching at kink points of the budget constraint. Such bunching should be observed in a frictionless labor market with utility maximizing workers. The stylized model of Chetty et al. (2011) allows workers to be work hour constrained on-the-job. However, workers can move to a job that offers their optimal hours if they are willing to pay search costs. The assumption of constraints within jobs and flexibility across jobs reflects the consensus of the literature on work hour constraints and job mobility. Euwals (2001), Böheim and Taylor (2004), Blundell, Brewer and Francesconi (2008), and Gong and Breunig (2014) consistently find that job movers adjust their actual work hours to a much larger extent in the preferred direction than job stayers. Thus, Blundell et al. (2008) conclude that "[...]at least to a first approximation, an adapted canonical labor supply model with hours flexibility across jobs cannot be rejected" (p. 450). However, the focus on the flexibility of actual work hours may produce an incomplete picture of the role of job changes because the actual resolution is not considered.

In this paper, we offer a comprehensive two-part analysis. We acknowledge the fact that constrained workers can adjust via two channels: actual and desired work hours (Reynolds \& Aletraris, 2006, 2010). Consequently, the first part of the analysis considers how these two adjustment channels differ for job movers and a comparable group of job stayers. This part reveals the anatomy of the average adjustments

\footnotetext{
${ }^{1}$ For example, in the sample for Germany used in this study, only $42 \%$ of the workers report being satisfied with their hours. $47 \%$ prefer to work less (overemployed) and 11\% prefer to work more (underemployed) (see also Figure 1).

2 The incidence of work hour constraints is widely documented and various explanations have been proposed for this labor market feature including inadequate matching (Altonji \& Paxson, 1988), long-term contracts and wage rigidity (Kahn \& Lang, 1992, 1996), work hour regulation (Rottenberg, 1995), asymmetric information on worker productivity (Landers, Rebitzer, \& Taylor, 1996; Sousa-Poza \& Ziegler, 2003), job insecurity (Stewart \& Swaffield, 1997), adjustment costs (Chetty et al., 2011), and fixed costs of employment (Johnson, 2011). A recent critical discussion about the orthodoxy to interpret observed work hours as labor supply is provided by Pencavel (2016).
} 
but provides no insights about the differences in the actual resolution of the mismatches. Therefore, the second part investigates whether job movers exhibit higher resolution rates than comparable job stayers. Further, the second part considers the differences in the probabilities of staying in the same mismatch or of switching mismatch type (i.e., over- $\leftrightarrow$ underemployment).

This two-part analysis combines and extends the ideas of earlier studies. The analysis builds on the work of Euwals (2001), Böheim and Taylor (2004), and Blundell et al. (2008), who all find larger average adjustments in actual work hours across jobs. However, they do not investigate whether higher work hour flexibility across jobs increases the probability of actually resolving mismatches. Nor do they consider adjustments to desired work hours, even though this channel reportedly plays an important role in mismatch resolution (Reynolds \& Aletraris, 2006, 2010).

Our study contributes to the existing literature in three dimensions. First, we include adjustments to desired hours to capture the complete adjustment process. ${ }^{3}$ Second, we evaluate whether increased work hour flexibility across jobs actually leads to a higher probability of resolving work hour mismatches. Third, we exploit information about the magnitude of the mismatch to improve interpretation of the results and to construct a more comparable group of job stayers. A reasonable interpretation of the changes in adjustment channels requires knowledge about the magnitude of the mismatch that has to be resolved. Furthermore, we include the prevailing magnitude of the mismatch as a control variable. This control variable is omitted or not available in previous studies, although it is very likely to affect the probability of job change and the extent of adjustment simultaneously. Finally, we carry out a number of robustness and plausibility checks to investigate the credibility of our results and provide a deeper understanding of the main findings.

Our results confirm previous findings that job change facilitates adjustment via changes in actual hours on a large scale. However, the adjustment in desired hours plays a non-negligible role for underemployed workers who cut substantially down their desired hours. This adjustment in desired hours is significantly smaller for underemployed job movers, such that it partly offsets the increased flexibility in actual hours. Turning to the resolution rate, our results show that job change does facilitate the resolution of work hour mismatches in most cases. However, job change is no panacea, for it also substantially increases the probability of switching to the diametric mismatch (i.e., over- $\leftrightarrow$ underemployment). In particular, underemployed job movers exhibit a substantially higher probability of ending up in overemployment in the new job.

The remainder of the paper is structured as follows: Section 2 outlines the findings and shortcomings of the related literature. Section 3 describes the data and lays out the econometric challenges. Section 4 explains our econometric strategy. Section 5 discusses the results. Section 6 concludes the paper.

\footnotetext{
${ }^{3}$ Reynolds and Johnson (2012) is the only study that we are aware of that distinguishes between both adjustment channels; however, its focus is on how work hour mismatches are affected by the birth of a child.
} 


\section{Related Literature}

Most studies that address the role of job mobility in the presence of work hour mismatches focus on the effect of job change on actual work hours. For example, Altonji and Paxson $(1986,1992)$ and MartinezGranado (2005) report that job movers adjust their actual work hours to a much larger extent than job stayers. They interpret this larger flexibility as evidence for work hour constraints. However, none of these studies takes the prevailing mismatch and its resolution into account. Rather, it is Euwals (2001) who first exploits additional information about individual workers' mismatch situations in the context of job change ${ }^{4}$ by estimating the average fraction of the mismatch that is resolved for job movers versus job stayers. His results for Dutch women indicate that overemployed job movers adjust their actual work hours to be $64 \%$ in line with their preferences, whereas overemployed stayers show an adjustment rate of $20 \%$. Likewise, underemployed job movers adjust $72 \%$ in the preferred direction, while underemployed stayers adjust 34\%. This higher adjustment of underemployed versus overemployed workers is confirmed by Böheim and Taylor (2004), using nine waves (1991-1999) of the British Household Panel Survey (BHPS).

Blundell et al. (2008) apply a difference-in-differences approach, exploiting different reforms that changed the incentives for single mothers to work either more or less. Using BHPS data, these authors show that the average adjustment in the preferred direction is substantially higher if they change jobs. Gong and Breunig (2014) find similar results for comparable reforms in Australia.

The cited analyses suffer from two shortcomings that prevent a definitive judgment about the effectiveness of job change in resolving work hour mismatches. First, these studies consider no information about the magnitude of the mismatch to be resolved. Yet without knowledge of the prevailing mismatch, results such as the average 8-hour adjustment for underemployed women estimated by Böheim and Taylor (2004) are hard to interpret meaningfully. For a mismatch of 5 hours, the adjustment would be too large, but for a mismatch of 10 hours, it would be too small. Moreover, missing information on prevailing mismatch magnitude hinders the construction of a comparable group of job stayers as it might be a crucial control variable. That is, those with larger mismatches could exhibit a higher probability of job change and also have to make larger adjustments to resolve their mismatch. Thus, any analysis that omits mismatch magnitude as a control variable potentially overestimates the difference between job movers and job stayers. Second, by reporting only average adjustments, these studies enable no assessment of the role played by job change in the actual resolution of mismatches. Even Euwals (2001), who reports the percentages to which workers can adjust their actual work hours, does not answer this question. It thus remains unclear whether the average adjustment of $72 \%$ would allow any worker to resolve a mismatch. This average effect would also be observed if one half of the workers made no adjustment at all and the other half adjusted by $144 \%$. The first half would maintain their mismatch, while the latter would overcompensate and end up in a diametric mismatch.

\footnotetext{
${ }^{4}$ Altonji and Paxson (1988) also use subjective data on work hour mismatches, but their focus is on wages rather than job change.
} 
Two studies by Reynolds and Aletraris $(2006,2010)$ do complement the actual work hour adjustment, by using multinomial logit models to assess the impact of a range of factors, including job mobility, on the probability of mismatch resolution in two waves of Australian and American panel data. First, Reynolds and Aletraris (2006) show that job change is generally associated with a significant and sizeable increase in the probability of resolving a mismatch. Reynolds and Aletraris (2010) find that for initially underemployed workers job change also increases the probability of switching into overemployment. A second essential contribution is that they emphasize the adjustment of desired work hours as a possible adjustment channel. The studies in the previous paragraphs neglect the possibility of adjusting desired hours as an adjustment channel. However, Reynolds and Aletraris (2006) provide evidence that changes in desired work hours contribute to mismatch resolution to an even larger extent than changes in actual work hours. With respect to job change, Reynolds and Aletraris (2010) also suggest that underemployed job movers adjust less through desired work hour adjustments than do job stayers. Nevertheless, as valuable as these ideas are in developing our two-part analysis, job change represents only one component of Reynolds and Aletraris's large set of determinants. Hence, whereas their investigation is more exploratory, our focus on job changes provides a detailed analysis of the differences between job movers and the situation in which they had to adjust on-the-job.

\section{Data}

\subsection{Preparation}

Our analysis is based on data from the German Socio-Economic Panel (SOEP) (Wagner, Frick, \& Schupp, 2007), the longest running longitudinal survey of private households and their living conditions in Germany. ${ }^{5}$ The SOEP is administered to a representative sample of about 12,000 households containing approximately 21,000 individuals. Specifically, we draw on 16 sequential waves from 1997 to 2012 to analyze individuals between 20 to 59 years ${ }^{6}$ who were employed for at least two subsequent periods. ${ }^{7}$ After excluding the self-employed and second job holders from the analysis, ${ }^{8}$ together with other preparatory steps, we are left with 96,510 observations stemming from 18,264 individuals. ${ }^{9}$

The SOEP asks respondents about actual work hours and about desired work hours given the potential earnings adjustment: "How many hours do you generally work per week, including any overtime?" and "If you could choose your own work hours, taking into account that your income would change according to the number of hours, how many hours would you want to work per week?" ${ }^{10}$ Based

\footnotetext{
${ }^{5}$ Socio-Economic-Panel (SOEP), data for years 1984-2012, version 29, SOEP, 2013. doi:10.5684/soep.v29

${ }^{6}$ We set this cutoff age in recognition of the finding that constrained workers close to retirement age adjust mainly by leaving the labor force early (Charles \& Decicca, 2007; Gielen, 2008), an adjustment channel at the extensive margin that is not the topic of our study.

${ }^{7}$ The analysis begins in 1997 because the crucial variable for desired work hours was not collected in 1996, a missing wave that in our dynamic approach would lead to a two-year break in the panel.

${ }^{8}$ Specifically, with regard to desired work hours, it is unclear whether respondents holding a second job refer to both first and second jobs or to the first job only (Heineck, 2009).

${ }^{9}$ The specific steps and a description of the dropped sample are documented in the Appendix B.

${ }^{10}$ The distribution of actual and desired work hours is shown in Figure A.3.
} 
on the responses, we calculate the difference between actual work hours (HA) and desired work hours $(H D)$ for individual $i$ at time $t$ designated by $D E V_{i t}=H A_{i t}-H D_{i t}$. A positive number indicates overemployment and a negative number indicates underemployment.

The analysis of the adjustment process requires the calculation of the first difference of actual work hours and desired work hours, respectively:

$$
\Delta H A_{i t}=H A_{i t}-H A_{i t-1} \text { and } \Delta H D_{i t}=H D_{i t}-H D_{i, t}-1
$$

As well as the first difference of the deviation between these two:

$$
\Delta D E V_{i t}=D E V_{i t}-D E V_{i, t}-1=\Delta H A_{i t}-\Delta H D_{i t}
$$

The relations in Equation 1 illustrate how changes in the mismatch variables can be decomposed into the two adjustment channels. This enables an assessment of whether an adjustment takes place in actual and/or desired work hours. The decomposition in Equation 1 plays a crucial role by revealing the anatomy of adjustment in the first part of our analysis.

We assign workers to three types of work hour mismatch: (i) underemployed: actual work hours more than 2.5 below desired work hours, (ii) unconstrained: absolute deviation of 2.5 and lower, and (iii) overemployed: actual work hours more than 2.5 above desired work hours, formally expressed as ${ }^{11}$

$$
T Y P E_{i t}=\left\{\begin{array}{l}
U N D E R_{i t} \text { if } D E V_{i t}<-2.5 \\
U N C O N_{i t} \text { if }\left|D E V_{i t}\right| \leq-2.5 \\
O V E R_{i t} \text { if } D E V_{i t}>-2.5 .
\end{array}\right.
$$

These mismatch types are then coded as dummy variables that constitute outcomes in the second part of our analysis. For example, the mean of $U N C O N_{i t}$ shows the fraction of unconstrained workers in period $t$ in the sample.

The focus of our analysis is to analyze how these outcome variables differ between job movers and job stayers. Job changes are characterized by a dummy variable that equals one if a job change occurs between the interviews at time $t$ and $t+1.12$

\subsection{Descriptives}

Our initial descriptive analysis illustrates the extent and development of work hour mismatches in Germany from 1997 to 2012. According to Figure 1, during this period only 38\% to 45\% of the workers

\footnotetext{
11 The choice of the threshold is motivated by the distribution of $D E V$ (see Figure A.2), which reveals a typical pattern of self-reported work hours (see, e.g., Otterbach \& Sousa-Poza, 2010). Most respondents think of actual and desired hours in terms of 5-hour categories, which explains the bunching of the DEV distribution at 5-hour intervals. In a robustness check, the range to be considered unconstrained is extended, but this does not affect the main findings.

${ }^{12}$ We use the variable JOBCH\$, provided by the GSOEP, that accounts for double counting in the raw data because of question phrasing. The main analysis does not distinguish between different types of job changes. Later, we also check for heterogeneous differences for different types of job changes. However, the necessary information is not available for all periods and job movers.
} 
were unconstrained as it is defined in the previous subsection. The fraction of overemployed workers is higher in most years, varying between $44 \%$ and $52 \%$. Underemployment is reported to a much smaller extent, at only $10 \%$ to $13 \%$ of the respondents. Figure 1 also reveals that the fraction of each mismatch type exhibits only relatively small variations over time. Further, it emphasizes the high prevalence of mismatch and the large fraction of overemployed workers in particular.

Insert Figure 1 about here

Figure A.1 depicts the distribution of the magnitude of work hour mismatches for constrained men and women, respectively. The histogram bars represent work hour mismatches aggregated into bins of 5 -hour intervals. The graph shows that about half of the constrained workers would like to work over 2.5 up to 7.5 hours per week more or less than they actually do. This amounts to between 0.5 and 1.5 hours per day in a standard five-day-work week, and thus might be seen as moderate mismatch. However, roughly the other half indicate substantial mismatches by reporting a desire to change hours by more than 7.5 hours per week.

Figure A.3 contrasts actual and desired work hours to investigate the distributions that underlie the mismatch variable, and characterizes the different gender-mismatch subsamples under investigation. Underemployed men report a large imbalance in the part-time sector. While 23\% of underemployed men work less than 32.5 hours, only 6\% prefer hours in this range. Interestingly, the majority of men who prefer more hours already work full-time, and 35\% would like to work 50 hours and more. These wannabe workaholic men are on average younger, less often married, and have fewer children than unconstrained and overemployed workers, as can be seen in Table A.1. In contrast to the workaholic underemployed men, the largest fraction of underemployed women prefers to work 40 hours, while currently working part-time ( $82 \%$ work 30 hours or less). This indicates that underemployed women mostly experience involuntary part-time work. Underemployed women also are more often married and have more children than other employed women. This reverses the pattern observed for their male counterparts.

While underemployed men and women show different characteristics, overemployed men and women show similar patterns. Most of them work more than 42.5 hours, but nearly nobody desires hours in this range. The number of hours that are mostly desired are in the range between 27.5 and 42.5 hours per week. In particular, overemployed men primarily prefer a standard 40-hour work week.

Table 1 provides an unconditional mean comparison for the outcome variables of interest between job movers and job stayers in the mismatch-gender subsamples. The first three numerical rows show differences in the adjustment channels. In principle, workers can use two adjustment channels (or a combination of both) to resolve a specific work hour mismatch: adjusting either actual work hours or desired work hours. Underemployed male job movers, for example, increase their actual weekly work hours on average by 8.5 while cutting down their desired work week by 2.6 hours. This leads to an 
average total adjustment of 11.1 hours (according to Equation 1), corresponding to an average absolute prevailing mismatch of also 11.1 hours in period $t$ (see first row in lower panel). Therefore, the average total adjustment closes the average gap between actual and desired hours completely. For all other groups, the average adjustment is substantially smaller than the average mismatch that should be resolved. Another interesting finding is that job stayers adjust at least as much in desired hours as in actual hours. This emphasizes the necessity to consider desired hours as the second adjustment channel.

Turning to the probabilities to report one of the three mismatch types, we see that the resolution rates are significantly higher for movers than for stayers. The only exception is underemployed men, who are insignificantly 2 percentage points more likely to resolve their mismatches if they remain in their job. The significant differences in the fractions of job movers and stayers who resolve their work hour mismatches are quite moderate, ranging from 4 to 8 percentage points. In general, the resolution rates are much smaller than one would expect with free hours choice. Instead, the differences in the fractions of job movers and stayers who end up in a diametric mismatch are quite substantial. For example, 33\% (21\%) of underemployed male (female) job movers end up being overemployed in the following period, whereas only $21 \%$ (13\%) of underemployed male (female) job stayers switch mismatch type. The fractions of overemployed job movers who end up being underemployed are about 3 times higher than the same fractions for stayers.

Insert Table 1 about here

The lower panel of Table 1 illustrates that job movers and job stayers differ significantly in the levels of actual and desired hours as well as the magnitudes of mismatch. The job movers in all gendermismatch subsamples exhibit higher prevailing mismatches, which stem from corresponding differences in the levels of actual and desired hours. Therefore, job movers require larger adjustments compared to job stayers, which might explain the small and negative differences in the resolution rates. Further, the larger required adjustments could partly explain the large differences in adjustments in actual hours found in previous studies, as they do not control for prevailing mismatches.

Job movers and stayers also differ in several other characteristics such as wages, job satisfaction, firm tenure, and age. In all subgroups, job movers show lower wages, lower levels of job satisfaction, shorter firm tenure, and younger age on average than job stayers. If we want to understand the role of job change in the adjustment process, we need to control for the differences in these confounding variables.

\section{Econometric Strategy}

We aim to analyze the role of job change in adjusting to work hour mismatches. Therefore, we need to 
understand how the observable constrained job movers would have adjusted if they had stayed in their previous job. In other words, the adjustment on-the-job is not observed and must be estimated. The previous section showed that job stayers differ substantially from job movers. Therefore, the empirical strategy aims to construct a group of job stayers that is comparable in observed characteristics to the group of job movers. We use propensity score matching to ensure that the observed differences between the two groups are not driven by confounding variables but by the fact that one group adjusts work hours across jobs and the other group within jobs.

The credibility of such an approach depends on the ability to control for the variables that simultaneously affect our outcomes of interest and the propensity to change jobs. The most important variables that should be controlled for are the levels of actual and desired hours in period $t$ and consequently the prevailing magnitude of mismatch. This ensures both that job movers and the matched stayers have the same initial position and also that differences in the adjustment during the next period do not mirror higher desired adjustments.

Most likely, making sure that job movers and their matched stayers start at the same levels does not fully control for other characteristics. However, this provision is crucial, as Table 1 shows several other characteristics that differ across movers and stayers. Those characteristics, along with more socioeconomic, job-related and regional factors should be balanced between job movers and the matched stayers to make them as comparable as possible. Fortunately, the SOEP data offer numerous variables that are useful for this analysis.

The necessity of controlling for socio-economic factors is derived from the labor supply literature, which identifies a variety of so-called "taste shifters". These are socio-economic factors that could shift desired work hours (Keane, 2011). At the same time such "taste shifters" are likely to influence the probability to change jobs. One example is age because younger people tend to be generally more flexible; this could be mirrored in larger adjustments and in a higher probability to change jobs. However, not only levels but also changes in socio-demographic factors should be included; especially changes in the household composition can induce changes in the desire to work and might, e.g., also increase the willingness to change jobs. The set of "taste shifters" considered in the analysis are:

Socio-demographic factors: age, education, household income, marital status, being a homeowner, being a foreigner, self-perceived health, disability status, number of children, birth of a child within last year, no others in need of care in household, divorce, and last child moved out; 13

The inclusion of job-related factors is straightforward because the conditions in the current job determine to a large extent the probability to change the job. At the same time, factors like wages are crucial determinants of desired labor supply. The variables considered in this block of confounders are therefore:

\footnotetext{
${ }^{13}$ We tried several more potential taste shifters, especially different measures for changes in the household composition (changes in: marital status, number of children in the household, persons in need of care, etc.). However, only the ones that survived different score tests were finally included. The same was done for job and regional variables discussed below.
} 
Job-related information: the magnitude of mismatch (DEV), actual work hours, hourly wages, job satisfaction, tenure, distance to work, firm size, public service, occupation, fixed-term contracts, overtime work, and whether or not overtime work is compensated;

The environment in which people live might also influence the opportunities to change jobs and at the same time affect work hours. For example, higher regional unemployment rates could lead to fewer opportunities to change jobs, but they also increase the willingness to work long hours because of job insecurity (Stewart \& Swaffield, 1997). Other regional factors could have a similar impact. We control for:

Regional variables: population density, East Germany, and the yearly regional unemployment rate on the federal state level (obtained from the Federal Employment Agency).

We account for possible business cycle effects and other year-specific effects by controlling for the year of observation. Finally, we consider over- and underemployed workers separately, which implicitly controls for the mismatch status in $t$. Thereby, we might be able to capture some unobservables that led to the mismatch situation in the first place; for example, employer characteristics related to the economic situation or contract details that prevent workers from flexibly choosing their actual work hours. We are therefore confident that unobservables at time $t$ or before are not driving the differences that we find between job movers and matched stayers. ${ }^{14}$

The balancing of the observable characteristics is operationalized by propensity score matching. This approach acknowledges that it is impossible to find at least one job stayer for each job mover with exactly the same characteristics that can be matched. Especially with the large set of observables in our case, the curse of dimensionality prevents implementing direct matching and thus balancing the controls in this way. Instead, the seminal work of Rosenbaum and Rubin (1983) shows that balancing can also be achieved by matching on the propensity score. In our application, this strategy requires us to match movers with stayers who exhibit the same probability of job change conditional on all confounding variables. Rosenbaum and Rubin's findings (1983) led to the development of several non-parametric and semi-parametric estimators that use propensity score matching. We apply a recent semi-parametric estimator proposed by Lechner, Miquel, and Wunsch (2011) and implemented by Huber, Lechner, and Steinmayr (2014), which is based on a one-to-many caliper matching algorithm with bias correction.

This estimator is semi-parametric in that it requires parametric estimation of the propensity score before the nonparametric matching step. ${ }^{15}$ We thus estimate parametric Probit models within the gendermismatch subsamples that include the socio-demographic, job-related, and regional variables as covariates. ${ }^{16}$ Actual work hours, tenure, and job satisfaction are included with a quadratic term; wages and income enter in logarithmic form. The mismatch variables enter in categories rounded to five.

\footnotetext{
${ }^{14}$ The robustness section provides evidence in favor of this statement.

${ }^{15}$ The advantages of using such semi-parametric estimators instead of purely parametric strategies are well documented and include a higher robustness to misspecification, (allowing) the possibility of effect heterogeneity, and explicit consideration of common support (Imbens \& Wooldridge, 2009).

${ }^{16}$ The probit estimates mark only a first step in obtaining the final estimator and should be interpreted with caution. Nevertheless, they indicate which variables are important in the selection process. Therefore, the results are reported in Appendix C.
} 
Similarly, we define age categories as 5-year intervals, and include dummies for each to account for nonlinearities in age. Also included are dummies for occupational categories and years. The matching is performed on the Mahalanobis distance defined by the estimated propensity score and the levels of the actual work hours and the mismatch variable. The inclusion of these two levels in the matching metric should improve the balancing of these most important confounders and ensure that the point of departure in the levels are as close as possible for job movers and matched stayers.

\section{Results}

\subsection{Main results}

Table 2 and the accompanying Figure 2 report and illustrate the estimation results for the adjustment channels of underemployed workers. The upper and lower bounds in the figures designate the average gap between actual and desired work hours. Workers who are able to resolve the mismatch fill this gap between the mismatch and the zero line by adjusting their actual work hours in the preferred direction (lower bars) and/or by adjusting their desired hours in the realized direction (upper bars). Hence, the white region between the two bars represents the average unresolved mismatch. The results reported in Table 2 reveal that the adjustment channels are significantly affected by job change. We can confirm the findings of previous studies that job change leads to a higher flexibility in actual work hours in the preferred direction. On average, underemployed men adjust their actual work hours by 4.2 hours more and underemployed women by 6.5 hours more compared to their matched stayers who adjust on-thejob. These numbers are calculated as the difference between the average actual work hour adjustment of job movers and the corresponding average adjustment of the matched stayers.

Job change also alters adjustment via changes in desired hours. The matched group of stayers adjusts their desired hours downwards by up to 3.6 hours. For job movers, this adaptation is significantly smaller (2.6 hours) and contributes less to the resolution of the mismatch. Thus, the increased flexibility of actual work hours across jobs is partly offset by the lower adjustments in desired hours. For women especially, this effect is substantial. Instead of a better adjustment of 6.5 hours suggested by actual hour changes through job change, the net adjustment for the decrease in the mismatch is only 4.6. Thus, a mere focus on the adjustment in actual hours would overestimate the effectiveness of job change to decrease the gap between actual and desired hours.

The results suggest that underemployed male job movers close their gap by nearly $100 \%$ in Figure 2. Thus, it would be tempting to conclude that job change is an effective way to resolve mismatches for underemployed workers. However, the results in Table 3 and Figure 3 show the probabilities of reporting a specific mismatch type in $t+1$ after underemployment in $t$, and emphasize the importance of analyzing the resolution rates in addition to the average adjustments. For example, the probability of underemployed job movers resolving their mismatch is about 38\% for both men and women but 37\% and 26\% for their matched stayers, respectively. Most remarkably, the higher flexibility in actual work hours of underemployed male job movers does not translate into a significantly higher resolution rate. The increased flexibility leads to a 13 percentage point higher probability of leaving underemployment 
but at the expense of a 12 percentage point increase in the probability of becoming overemployed in the next period. Likewise, female job movers exhibit a higher probability of switching into overemployment (27\%). This is more than twice as high as compared to their matched stayers (13\%), leading to a 14 percentage point higher risk of ending up in overemployment after job change. However, their resolution rate also increases by 12 percentage points through job change. On the one hand, the findings for underemployed workers reveal that the higher flexibility through job change substantially increases the probability of leaving underemployment, especially for women. On the other hand, a large fraction of workers seems to overshoot and switch into a new job where they prefer to work less.

The results for overemployed workers are presented in the Tables 4 and 5 as well as in the accompanying Figures 5 and 6. In general, among overemployed workers actual and desired work hours are less flexible than among underemployed workers. The average adjustments are much less complete, although job movers' actual work hour reduction is at least twice as high (2.8 hours for men and 3.5 hours for women) as compared to their matched stayers (1.4 hours for men and women). We observe a significant increase in the flexibility of actual hours but on a much smaller scale. Overemployed male job movers are able to decrease their actual work hours by 1.4 and overemployed female job movers by 2.1 hours more than their matched stayers. The adjustments of desired work hours are negligible (about a 1 hour increase) regardless of job mobility and gender. Therefore, the higher flexibility in actual hours translates directly into a better total adjustment.

The much lower work hour flexibility for overemployed compared to underemployed is also mirrored in lower resolution rates. Nevertheless, resolution rates among both male and female job movers are significantly higher (by 5 percentage points) compared to their matched stayers. The probability of switching into underemployment is about twice as high among job movers than among matched stayers, but amounts to a moderate fraction of $12 \%$ (6\%) for female (male) job movers. In addition, the results clearly show that the majority of overemployed workers (more than $70 \%$ in case of no job change) stays overemployed even after a job change (more than 58\%).

Insert Tables 2 - 5 and Figures 2 - 5 about here

\subsection{Different types of job change}

The main analysis does not distinguish different types of job change. This subsection uses additional information about the reasons for and the direction of job change to analyze possible heterogeneous differences for different types of job changes. Unfortunately, this information is not available for all observed job changes, partly because the questions were not consistently asked in the same manner and partly due to missing values.

The most obvious distinction is to look at differences between voluntary and forced job change. One 
might argue that constrained job quitters search on-the-job for a new job and find one that meets their desired hours. On the other hand, constrained workers who lose their job for external reasons might accept job offers that deviate from their desired hours in order to avoid long spells of unemployment. The implication would be that the latter group drives the low resolution rates. This argumentation is not supported by the results reported in Table A.2 and Table A.3. Overemployed men in Table A.2 exhibit no significantly higher resolution rates if they voluntarily change jobs. In contrast, forced job movers increase their resolution rate by 8.5 percentage points, which is nearly twice as much as the respective subsample in the baseline. Overemployed women are the only subgroup in which job quitters show a substantially higher resolution rate if they move voluntarily. However, this difference is not significant at a $10 \%$ level. In all, the comparison of voluntary and forced job change shows that the low adjustment and resolution rates are mainly driven by job quitters.

The results in Table A.4 and Table A.5 investigate differences between across and within employer changes. The results in Table A.4 are very close to the baseline results because most reported job changes occur across employers. Therefore the number of job movers within employers is very limited. For the underemployed within job movers (Table A.5), with less than 100 observed job movers, the resulting huge standard errors prevent us from drawing any conclusion about this subgroup. However, the results on overemployed-within-employer job movers show nearly no significant differences in the adjustments between movers and matched stayers. This could indicate that work hour constraints are binding within employers, so that the flexibility gains require not only to change jobs but also employers.

\subsection{Robustness Checks}

This subsection provides several robustness checks. We discuss potential threats to our empirical strategy and provide evidence that they are not likely to invalidate our presented results. The most critical points are discussed with the help of Figure 6. The figure extends the considered time horizon by two years and shows the evolution of the variables of interest in $t-1, t, t+1$, and $t+2$ for movers and matched stayers. ${ }^{17}$

Figure 6 confirms that our estimator is successfully equalizing the levels in period $t$. This is not surprising, as we condition on pre-job change levels in the propensity score and the Mahalanobis distance. It is much more important for the credibility of our results that also the changes from $t-1$ to $t$ are balanced by conditioning on the observed levels and other confounders in period $t .{ }^{18}$ The black lines show that job movers experience on average substantial increases in the magnitude of mismatch in the period before they change jobs. This results from diverging actual and desired work hours in all subsamples. The grey lines of the matched stayers nearly exactly mimic the observed movers before $t$, although we use no control variables before that period. If unobserved heterogeneity drove our results, the paths should be different. This observation makes us confident that we are able to construct a credible

\footnotetext{
${ }^{17}$ We lose roughly half of the observation because workers must be observed in employment in four subsequent waves. Table A.8 shows that the estimates for this restricted sample are surprisingly similar to the baseline results.

${ }^{18}$ Only the changes for underemployed men deviate slightly but not significantly.
} 
comparison group and that unobserved heterogeneity plays no important role for the estimates. However, if movers and matched stayers face systematically different changes in unobserved confounders from $t$ to $t+1$, this could still bias our estimates.

Our main results show that a large fraction of underemployed job movers ends up in overemployment. One plausible explanation for this finding could be that job movers must familiarize themselves with new topics at the new job. This would require longer actual hours in the beginning, that should decrease after a phase of familiarization. Figure 6 shows no evidence for such an explanation, because male job movers show rather constant actual hours from $t+1$ to $t+2$ and female job movers even show a slight increase.

Insert Figure 6 about here

A similar concern is tackled in Table A.6. where we exclude workers who changed their jobs within three months after the interview in $t$. The results for this subsample are again similar to the baseline results and indicate that anticipation of a new job does not invalidate our estimates.

The definition of the types of mismatch is a fundamental building block. Therefore, we need to check whether our results are sensitive to changes in this crucial definition. To this end, we have redone the analysis with a more generous criterion to classify unconstrained workers. The definition of being unconstrained is now based on the rule $U N C O N_{i t}$ if $\left|D E V_{i t}\right|<5$. As a consequence, between $15 \%$ and $20 \%$ fewer workers are considered as constrained in the different subsamples. Further, the range for constrained workers to resolve the mismatch is nearly doubled. Table A.7 reports the corresponding results. The redefinition leads to larger adjustments for both movers and stayers. This can be attributed to the fact that the average mismatch to be resolved is increased in the constrained subgroups. Further, both movers and matched stayers exhibit higher levels of resolution rates compared to the baseline results. However, the differences between both groups are rather stable and show at most moderate increases in the resolution rates. Additionally, we observe substantial increases in the probability to switch mismatches even after the redefinition.

\section{Conclusions}

As in previous studies, our results provide evidence of greater flexibility in actual work hours across jobs than within jobs. Constrained job movers more than double their adjustments in the preferred direction compared to job stayers with the same prevailing mismatch. Previous studies stopped at this point and concluded that job mobility helps to overcome work hour mismatches. However, our analysis goes beyond the focus on average changes in actual hours and additionally considers adjustments in desired hours and mismatch resolution rates to provide a more differentiated view on the role of job change in this context.

Adjustments in desired hours are crucial to understand the full anatomy of the adjustment process of 
constrained workers. The importance of this adjustment channel is already emphasized by the work of Reynolds and Aletraris (2006, 2010) for the U.S. and Australia. We find that this channel is also important for German workers. In particular, underemployed workers who adjust on-the-job cut down their desired work hours substantially. Underemployed job movers use this channel to a smaller extent, such that the gain in flexibility of actual hours for job movers is attenuated. In contrast to underemployed workers, overemployed workers increase their desired work hours only marginally. This finding is consistent with the results of Loog, Dohmen and Vendrik (2012), who analyze adjustments in desired hours among German civil servants and public sector employees when the length of the standard work week was changed. Similar to our results, they find that desired hours adjust quickly to lower actual work hours but only marginally to increased actual work hours.

The combination of adjustments in both actual and desired work hours determines whether or not constrained workers resolve their mismatch. Our results show that the substantially increased flexibility in actual hours on average translates into only moderate increases in the resolution rate of mismatches on the individual level. The observed resolution rates of job movers are below $40 \%$ and at most 12 percentage points larger than the rates of comparable job stayers. Previous studies interpret the increased flexibility in actual hours via job changes as evidence for free hour choice across jobs - an essential assumption of most models of labor supply. However, the consideration of resolution rates shows that such interpretation is not supported in our application. Instead, our results confirm the existence of work hour constraints consistent with previous studies by Altonji and Paxson (1986, 1988, 1992), MartinezGranado (2005) and Chetty et al. (2011). Therefore, our empirical results favor models that allow for constrained hour choices in every situation (Beffy, Blundell, Bozio, \& Laroque, 2015; Bloemen, 2000, 2008; Kawata, 2015).

In all, the results of our study highlight the fact that job change is no panacea for resolving work hour mismatches. Instead, overemployment prevails for the majority of workers. We observe that already overemployed workers have severe problems in leaving overemployment even after a job change. Additionally, underemployed workers switch to a large extent into overemployment, especially if they change jobs. Further research should deepen our understanding of whether and to what extent labor market rigidities such as fixed costs of employment (Johnson, 2011) or job insecurity (Steward \& Swaffield, 1997) drive individuals into overemployment and keep them there. The adverse consequences of work hour mismatches on health (Bassanini \& Caroli, 2015; Bell et al., 2012) as well as on job satisfaction and life satisfaction (Kugler et al., 2014; Wooden et al., 2009) reinforce the necessity to identify the underlying reasons for work hour mismatches issuing from both sides of the labor market. 


\section{References}

Altonji, J. G., \& Paxson, C. H. (1986). Job characteristics and hours of work. In Research in Labor Economics (Vol. 8, pp. 1-55). Greenwich: Westview Press.

Altonji, J. G., \& Paxson, C. H. (1988). Labor Supply Preferences, Hours Constraints, and Hours-Wage Trade-Offs. Journal of Labor Economics, 6(2), 254-76.

Altonji, J. G., \& Paxson, C. H. (1992). Labor Supply, Hours Constraints, and Job Mobility. The Journal of Human Resources, 27(2), 256-278. http://doi.org/10.2307/145735

Bassanini, A., \& Caroli, E. (2015). Is Work Bad for Health? The Role of Constraint versus Choice. Annals of Economics and Statistics, (119-120), 13-37. http://doi.org/10.15609/annaeconstat2009.119-120.13

Beffy, M., Blundell, R., Bozio, A., \& Laroque, G. (2015). Labour supply and taxation with restricted choices (No. 15/02). IFS Working Papers.

Bell, D., Otterbach, S., \& Sousa-Poza, A. (2012). Working Hours Constraints and Health. Annales d'Economie et de Statistique, (105-106), 35-54.

Bloemen, H. G. (2000). A model of labour supply with job offer restrictions. Labour Economics, 7(3), 297-312. http://doi.org/10.1016/S0927-5371(00)00005-1

Bloemen, H. G. (2008). Job Search, Hours Restrictions, and Desired Hours of Work. Journal of Labor Economics, 26(1), 137-179. http://doi.org/10.1086/522069

Blundell, R., Brewer, M., \& Francesconi, M. (2008). Job Changes and Hours Changes: Understanding the Path of Labor Supply Adjustment. Journal of Labor Economics, 26(3), 421-453. http://doi.org/10.1086/588245

Böheim, R., \& Taylor, M. P. (2004). Actual and Preferred Working Hours. British Journal of Industrial Relations, 42(1), 149-166. http://doi.org/10.1111/j.1467-8543.2004.00308.x

Charles, K. K., \& Decicca, P. (2007). Hours Flexibility and Retirement. Economic Inquiry, 45(2), 251-267. http://doi.org/10.1111/j.1465-7295.2006.00009.x

Chetty, R., Friedman, J. N., Olsen, T., \& Pistaferri, L. (2011). Adjustment Costs, Firm 
Responses, and Micro vs. Macro Labor Supply Elasticities: Evidence from Danish Tax Records. The Quarterly Journal of Economics, 126(2), 749-804. http://doi.org/10.1093/qje/qjr013

Euwals, R. (2001). Female Labour Supply, Flexibility of Working Hours, and Job Mobility. The Economic Journal, 111(471), C120-C134.

Gielen, A. C. (2008). Working hours flexibility and older workers’ labor supply. Oxford Economic Papers, gpn035. http://doi.org/10.1093/oep/gpn035

Gong, X., \& Breunig, R. (2014). Channels of labour supply responses of lone parents to changed work incentives. Oxford Economic Papers, 66(4), 916-939. http://doi.org/10.1093/oep/gpu022

Heineck, G. (2009). The determinants of secondary jobholding in Germany and the UK. Zeitschrift Für ArbeitsmarktForschung, 42(2), 107-120. http://doi.org/10.1007/s12651-009-0008-8

Huber, M., Lechner, M., \& Steinmayr, A. (2014). Radius matching on the propensity score with bias adjustment: tuning parameters and finite sample behaviour. Empirical Economics, 49(1), 1-31. http://doi.org/10.1007/s00181-014-0847-1

Johnson, W. R. (2011). Fixed Costs and Hours Constraints. Journal of Human Resources, 46(4), 775-799. http://doi.org/10.3368/jhr.46.4.775

Kahn, S., \& Lang, K. (1992). Constraints on the Choice of Work Hours: Agency Versus Specific-Capital. The Journal of Human Resources, 27(4), 661-678. http://doi.org/10.2307/146080

Kahn, S., \& Lang, K. (1996). Hours Constraints and the Wage/Hours Locus. The Canadian Journal of Economics / Revue Canadienne d'Economique, 29, S71-S75. http://doi.org/10.2307/135963

Kawata, K. (2015). Work hour mismatches and on-the-job search. Economic Modelling, 47(C), 280-291. 
Keane, M. P. (2011). Labor Supply and Taxes: A Survey. Journal of Economic Literature, 49(4), 961-1075. http://doi.org/10.1257/jel.49.4.961

Kugler, F., Wiencierz, A., \& Wunder, C. (2014). Working hours mismatch and well-being: comparative evidence from Australian and German panel data (LASER Discussion Paper No. 82). University of Erlangen-Nuernberg.

Landers, R. M., Rebitzer, J. B., \& Taylor, L. J. (1996). Rat Race Redux: Adverse Selection in the Determination of Work Hours in Law Firms. The American Economic Review, 86(3), 329-348.

Lechner, M., Miquel, R., \& Wunsch, C. (2011). Long-Run Effects of Public Sector Sponsored Training in West Germany. Journal of the European Economic Association, 9(4), 742-784. http://doi.org/10.1111/j.1542-4774.2011.01029.x

Lechner, M., \& Strittmatter, A. (2014). Practical procedures to deal with common support problems in matching estimation (No. 2014-10). Department of Economics, University of St. Gallen.

Loog, B., Dohmen, T., \& Vendrik, M. (2012). The impact of changes in the standard workweek on preferences for labor supply. Maastricht University Working Paper.

Martinez-Granado, M. (2005). Testing labour supply and hours constraints. Labour Economics, 12(3), 321-343. http://doi.org/10.1016/j.labeco.2003.11.007

Otterbach, S. (2010). Mismatches Between Actual and Preferred Work Time: Empirical Evidence of Hours Constraints in 21 Countries. Journal of Consumer Policy, 33(2), 143-161. http://doi.org/10.1007/s10603-009-9116-7

Otterbach, S., \& Sousa-Poza, A. (2010). How Accurate are German Work-time Data? A Comparison of Time-diary Reports and Stylized Estimates. Social Indicators Research, 97(3), 325-339. http://doi.org/10.1007/s11205-009-9504-z

Pencavel, J. (2016). Whose Preferences Are Revealed in Hours of Work? Economic Inquiry, 54(1), 9-24. http://doi.org/10.1111/ecin.12276 
Reynolds, J., \& Aletraris, L. (2006). Pursuing Preferences: The Creation and Resolution of Work Hour Mismatches. American Sociological Review, 71(4), 618-638.

Reynolds, J., \& Aletraris, L. (2010). Mostly Mismatched With a Chance of Settling Tracking Work Hour Mismatches in the United States. Work and Occupations, 37(4), 476-511. http://doi.org/10.1177/0730888410383245

Reynolds, J., \& Johnson, D. R. (2012). Don’t Blame the Babies: Work Hour Mismatches and the Role of Children. Social Forces, 131-155. http://doi.org/10.1093/sf/sos070

Rottenberg, S. (1995). Regulation of the hours of work and its “Externalities” defenses. Journal of Labor Research, 16(1), 97-104. http://doi.org/10.1007/BF02685715

Sousa-Poza, A., \& Ziegler, A. (2003). Asymmetric information about workers’ productivity as a cause for inefficient long working hours. Labour Economics, 10(6), 727-747. http://doi.org/10.1016/S0927-5371(03)00016-2

Stewart, M. B., \& Swaffield, J. K. (1997). Constraints on the Desired Hours of Work of British Men. The Economic Journal, 107(441), 520-535.

Wagner, G. G., Frick, J. R., \& Schupp, J. (2007). The German Socio-Economic Panel Study (SOEP) - Scope, Evolution and Enhancements. Schmollers Jahrbuch: Journal of Applied Social Science Studies, 127, 139-169.

Wooden, M., Warren, D., \& Drago, R. (2009). Working Time Mismatch and Subjective Wellbeing. British Journal of Industrial Relations, 47(1), 147-179. http://doi.org/10.1111/j.1467-8543.2008.00705.x 
Figures and Tables

Table 1: Unconditional mean comparisons of outcome and control variables

\begin{tabular}{|c|c|c|c|c|c|c|c|c|}
\hline & \multicolumn{4}{|c|}{ Underemployed in $t$} & \multicolumn{4}{|c|}{ Overemployed in $t$} \\
\hline & \multicolumn{2}{|c|}{ Men } & \multicolumn{2}{|c|}{ Women } & \multicolumn{2}{|c|}{ Men } & \multicolumn{2}{|c|}{ Women } \\
\hline & Movers & Stayers & Movers & Stayers & Movers & Stayers & Movers & Stayers \\
\hline \multicolumn{9}{|l|}{ Outcomes: } \\
\hline$\Delta H A_{t+1}$ & $8.478^{* * *}$ & 2.375 & $9.144 * * *$ & 2.264 & $-2.780 * * *$ & -1.076 & $-3.565 * * *$ & -1.057 \\
\hline$\Delta H D_{t+1}$ & $-2.632 * * *$ & -4.167 & $-0.621 * * *$ & -2.419 & 1.100 & 1.049 & 1.386 & 1.383 \\
\hline$\Delta D E V_{t+1}$ & $11.110^{* * *}$ & 6.542 & $9.766^{* * *}$ & 4.683 & $-3.880 * * *$ & -2.125 & $-4.951 * * *$ & -2.44 \\
\hline$O V E R_{t+1}$ & $0.331^{* * *}$ & 0.207 & $0.268 * * *$ & 0.127 & $0.664^{* * *}$ & 0.739 & $0.581^{* * *}$ & 0.714 \\
\hline$U N C O N_{t+1}$ & 0.379 & 0.401 & $0.381^{* * *}$ & 0.298 & $0.272^{* * *}$ & 0.236 & $0.300^{* * *}$ & 0.245 \\
\hline$U N D E R_{t+1}$ & $0.291 * * *$ & 0.392 & $0.350 * * *$ & 0.575 & $0.064 * * *$ & 0.026 & $0.119 * * *$ & 0.04 \\
\hline \multicolumn{9}{|c|}{ Main confounder: } \\
\hline$D E V_{t}$ & $-11.125^{* * *}$ & -8.309 & $-11.520 * * *$ & -9.348 & $10.275^{* * *}$ & 9.363 & $9.577^{*}$ & 9.284 \\
\hline$H A_{t}$ & $32.083^{* * *}$ & 36.851 & $19.147^{* * *}$ & 21.33 & $48.368^{* * *}$ & 47.036 & $41.876^{* * *}$ & 40.331 \\
\hline$H D_{t}$ & $43.207^{* * *}$ & 45.16 & 30.668 & 30.678 & $38.093^{* * *}$ & 37.672 & $32.299^{* * *}$ & 31.047 \\
\hline Hourly wage & $7.908^{* * *}$ & 10.056 & $6.911^{* * *}$ & 7.819 & $8.608^{* * *}$ & 10.744 & $6.806^{* * *}$ & 8.198 \\
\hline Job satisfaction & $6.243^{* * *}$ & 6.933 & $6.221^{* * *}$ & 6.95 & $6.284^{* * *}$ & 6.994 & $6.228^{* * *}$ & 6.925 \\
\hline Firm tenure & $3.408^{* * *}$ & 8.667 & $3.355^{* * *}$ & 7.41 & $5.468^{* * *}$ & 11.755 & $4.819 * * *$ & 10.95 \\
\hline Age & $31.868^{* * *}$ & 37.644 & $35.855^{* * *}$ & 40.98 & $36.125^{* * *}$ & 41.73 & $34.315^{* * *}$ & 41.449 \\
\hline Observations & 523 & 3,063 & 913 & 6,073 & 1,965 & 24,200 & 1,507 & 17,768 \\
\hline$\%$ of movers & \multicolumn{2}{|c|}{$14.58 \%$} & \multicolumn{2}{|c|}{$13.07 \%$} & \multicolumn{2}{|c|}{$7.51 \%$} & \multicolumn{2}{|c|}{$7.82 \%$} \\
\hline
\end{tabular}

Notes: Variable means of main confounders based on the sample used for analysis. * / ** / *** indicate $10 \%$ / 5\% / $1 \%$ significance level of a t-test on the equality of means between job movers and job stayers.

Figure 1: Distribution of the types of mismatch over time

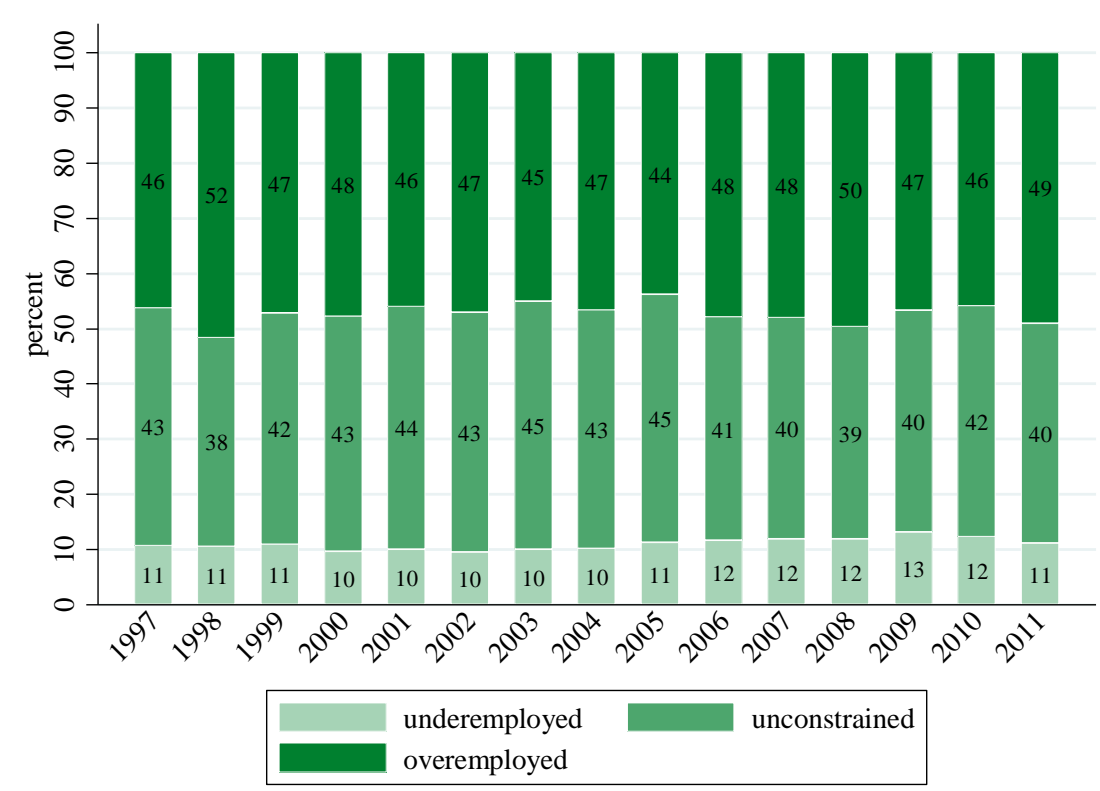

Notes: The bars report the fractions of overemployed (upper part, wants to work $>2.5$ hours less than currently), unconstrained (middle part), and underemployed (lower part, wants to work $>2.5$ hours more than currently) in the analyzed sample. 
Figure 2: Adjustments in actual and desired work hours, underemployed in $t$

Underemployed in $\mathrm{t}$

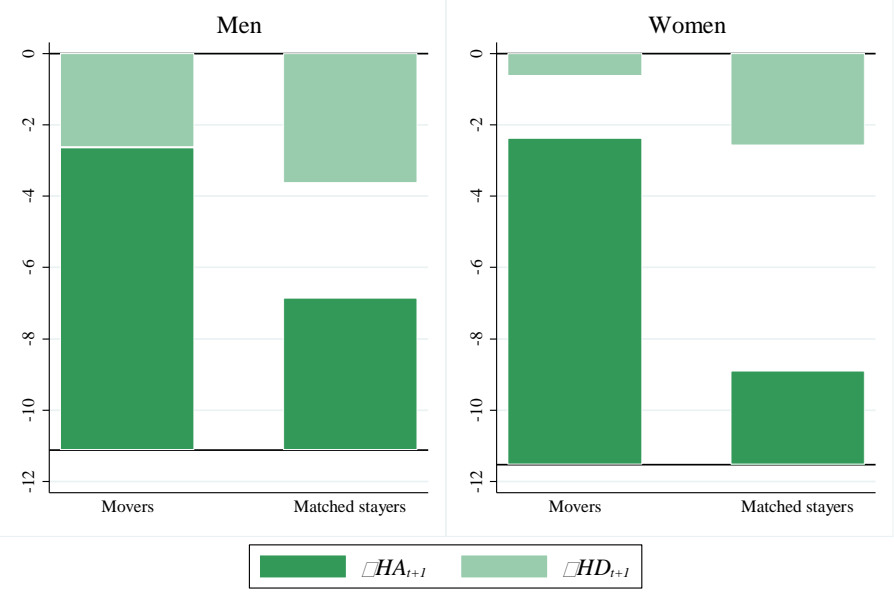

Table 2: Adjustments in actual and desired work hours

\begin{tabular}{|c|c|c|c|c|c|c|c|c|}
\hline & \multicolumn{4}{|c|}{ Men } & \multicolumn{4}{|c|}{ Women } \\
\hline & Movers & Stayers & Difference & S.E. & Movers & Stayers & Difference & S.E. \\
\hline$\Delta H A_{t+1}$ & 8.478 & 4.271 & $4.208 * * *$ & 0.668 & 9.144 & 2.616 & $6.529 * * *$ & 0.480 \\
\hline$\Delta H D_{t+1}$ & -2.632 & -3.622 & $0.991^{* *}$ & 0.494 & -0.621 & -2.576 & $1.954^{* * *}$ & 0.372 \\
\hline$\Delta D E V_{t+1}$ & 11.110 & 7.893 & $3.217^{* * *}$ & 0.681 & 9.766 & 5.191 & $4.574 * * *$ & 0.466 \\
\hline$\varnothing D E V_{t}$ & \multicolumn{2}{|c|}{-11.125} & & & \multicolumn{2}{|c|}{-11.520} & & \\
\hline$\Delta D E V_{t+1} / \varnothing D E V_{t}$ & $-99.87 \%$ & $-70.95 \%$ & $-28.92 \%$ & & $-84.77 \%$ & $-45.06 \%$ & $-39.71 \%$ & \\
\hline Observations & 523 & 3,063 & & & 913 & 6,073 & & \\
\hline
\end{tabular}

Notes: Standard errors are based on 4999 bootstrap replications. The bootstraps are clustered on individual level. * $* * * * * *$ indicate significance at a $10 \%$ / 5\% / 1\% level.

Figure 3: Probabilities of remaining in, resolving, switching mismatch, underemployed in $t$

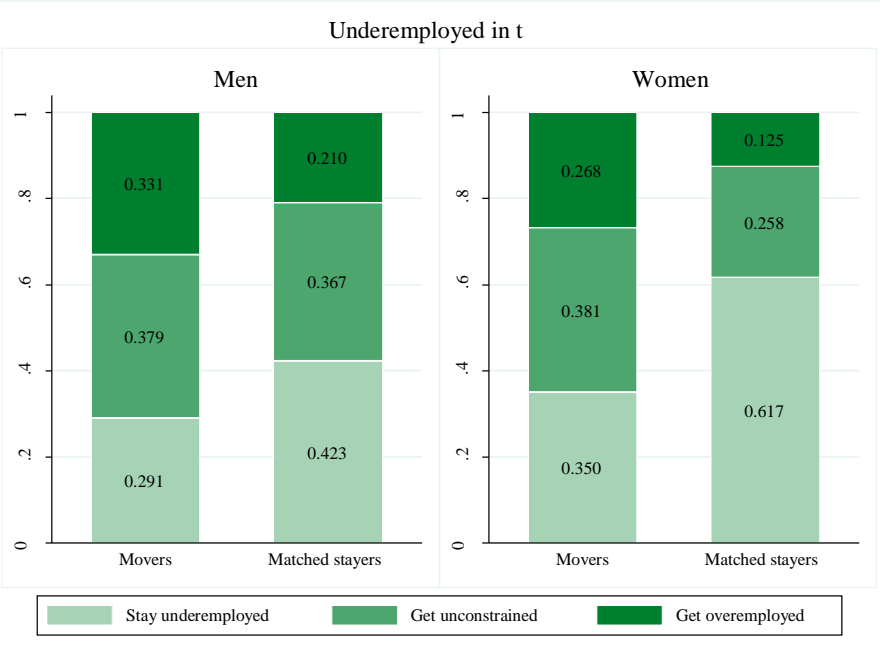

Table 3: Probabilities of remaining in, resolving, switching mismatch, underemployed in $t$

\begin{tabular}{|c|c|c|c|c|c|c|c|c|}
\hline \multirow[b]{2}{*}{ Mismatch in $t+1$} & \multicolumn{4}{|c|}{ Men } & \multicolumn{4}{|c|}{ Women } \\
\hline & Movers & Stayers & Difference & S.E. & Movers & Stayers & Difference & S.E. \\
\hline$O V E R_{t+1}$ & 0.331 & 0.210 & $0.121^{* * *}$ & 0.027 & 0.268 & 0.125 & $0.143^{* * *}$ & 0.019 \\
\hline$U_{N C O N}{ }_{t+1}$ & 0.379 & 0.367 & 0.011 & 0.030 & 0.381 & 0.258 & $0.123 * * *$ & 0.022 \\
\hline$U N D E R_{t+1}$ & 0.291 & 0.423 & $-0.132 * * *$ & 0.031 & 0.350 & 0.617 & $-0.266^{* * *}$ & 0.023 \\
\hline Observations & 523 & 3,063 & & & 913 & 6,073 & & \\
\hline
\end{tabular}

Notes: Standard errors are based on 4999 bootstrap replications. The bootstraps are clustered on individual level. $* / * * / * * *$ indicate significance at a $10 \%$ / $5 \%$ / $1 \%$ level. 
Figure 4: Adjustments in actual and desired work hours, overemployed in $t$

Overemployed in $\mathrm{t}$

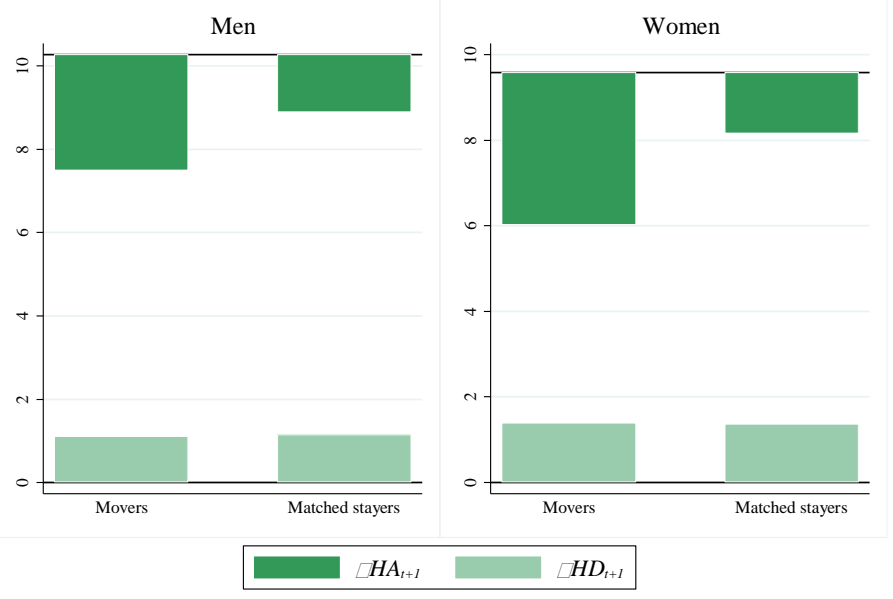

Table 4: Adjustments in actual and desired work hours, overemployed in $t$

\begin{tabular}{|c|c|c|c|c|c|c|c|c|}
\hline & \multicolumn{4}{|c|}{ Men } & \multicolumn{4}{|c|}{ Women } \\
\hline & Movers & Stayers & Difference & S.E. & Movers & Stayers & Difference & S.E. \\
\hline$\Delta H A_{t+1}$ & -2.780 & -1.379 & $-1.401^{* * *}$ & 0.249 & -3.565 & -1.440 & $-2.126^{* * *}$ & 0.298 \\
\hline$\Delta H D_{t+1}$ & 1.100 & 1.168 & -0.068 & 0.190 & 1.386 & 1.363 & 0.023 & 0.225 \\
\hline$\Delta D E V_{t+1}$ & -3.880 & -2.547 & $-1.333^{* * *}$ & 0.260 & -4.951 & -2.803 & $-2.148 * * *$ & 0.288 \\
\hline$\varnothing D E V_{t}$ & \multicolumn{2}{|c|}{10.275} & & & \multicolumn{2}{|c|}{9.577} & & \\
\hline$\Delta D E V_{t+1} / \varnothing D E V_{t}$ & $-37.77 \%$ & $-24.79 \%$ & $-12.98 \%$ & & $-51.69 \%$ & $-29.26 \%$ & $-22.43 \%$ & \\
\hline Observations & 1,965 & 24,200 & & & 1,507 & 17,768 & & \\
\hline
\end{tabular}

Notes: Standard errors are based on 4999 bootstrap replications. The bootstraps are clustered on individual level. $*$ / $* *$ / $* * *$ indicate significance at a $10 \%$ / $5 \%$ / $1 \%$ level.

Figure 5: Probabilities of remaining in, resolving, switching mismatch, overemployed in $t$

Overemployed in $\mathrm{t}$

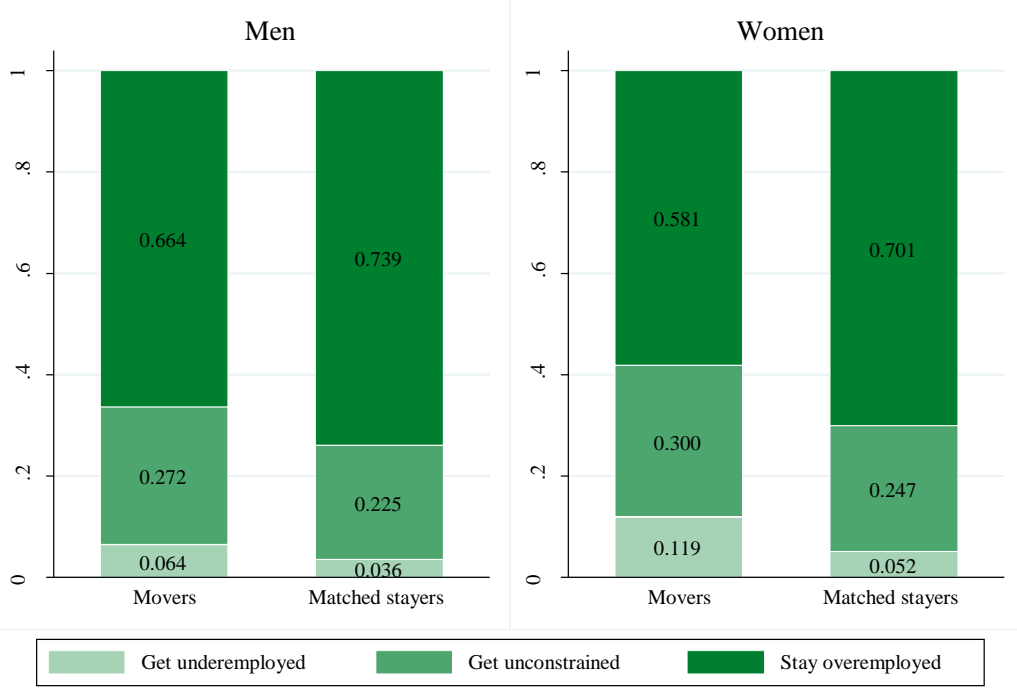

Table 5: Probabilities of remaining in, resolving, switching mismatch, underemployed in $t$

\begin{tabular}{|c|c|c|c|c|c|c|c|c|}
\hline \multirow[b]{2}{*}{ Mismatch in $t+1$} & \multicolumn{4}{|c|}{ Men } & \multicolumn{4}{|c|}{ Women } \\
\hline & Movers & Stayers & Difference & S.E. & Movers & Stayers & Difference & S.E. \\
\hline$O V E R_{t+1}$ & 0.664 & 0.739 & $-0.075^{* * *}$ & 0.015 & 0.581 & 0.701 & $-0.121^{* * *}$ & 0.017 \\
\hline$U_{N C O N}{ }_{t+1}$ & 0.272 & 0.225 & $0.047^{* * *}$ & 0.014 & 0.300 & 0.247 & $0.053^{* * *}$ & 0.016 \\
\hline$U N D E R_{t+1}$ & 0.064 & 0.036 & $0.028 * * *$ & 0.007 & 0.119 & 0.052 & $0.068 * * *$ & 0.010 \\
\hline Observations & 1,965 & 24,200 & & & 1,507 & 17,768 & & \\
\hline
\end{tabular}

Notes: Standard errors are based on 4999 bootstrap replications. The bootstraps are clustered on individual level. * / ** / *** indicate significance at a $10 \%$ / $5 \%$ / $1 \%$ level. 
Figure 6: Evolution of $H A, H D$ and $D E V$ around the job change between $t$ and $t+1$

Underemployed in $\mathrm{t}$

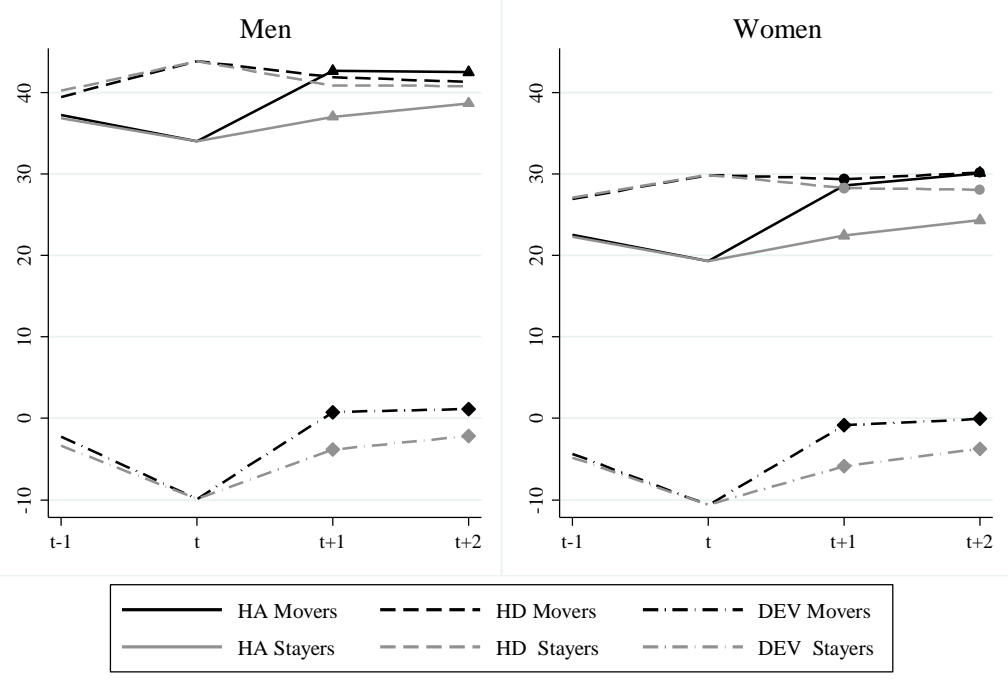

Overemployed in $\mathrm{t}$

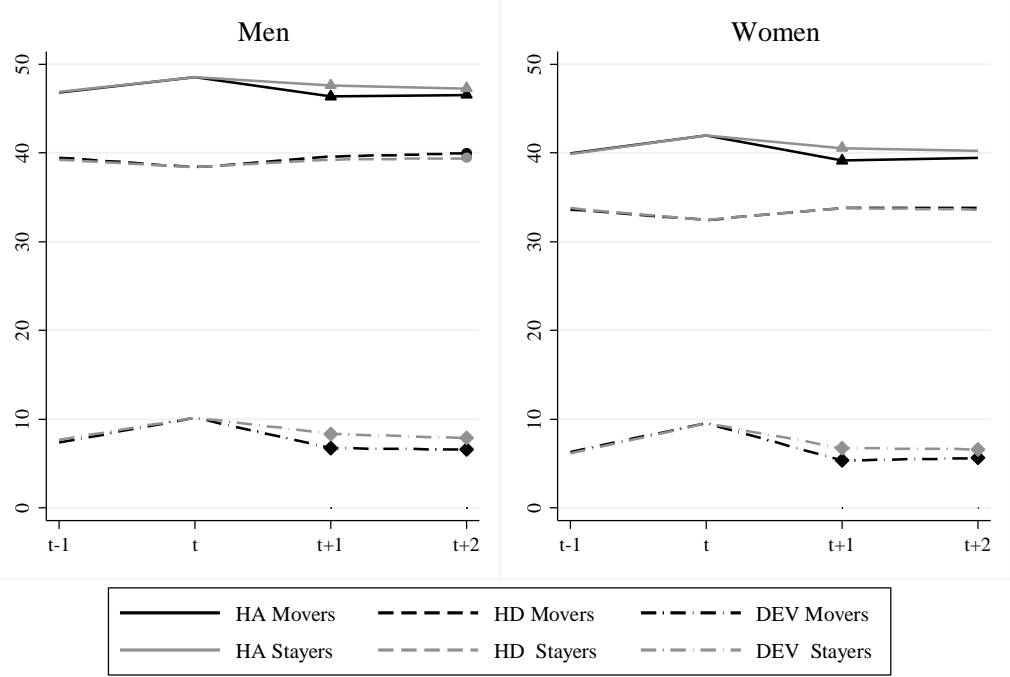

Notes: Triangles, dots, and squares indicate that the differences between movers and matched stayers are statistically significant at the 5\% level. Inference is based on 4999 bootstraps clustered at the individual level. 


\section{Appendix A}

Figure A.1: Distribution of mismatch variable for constrained workers
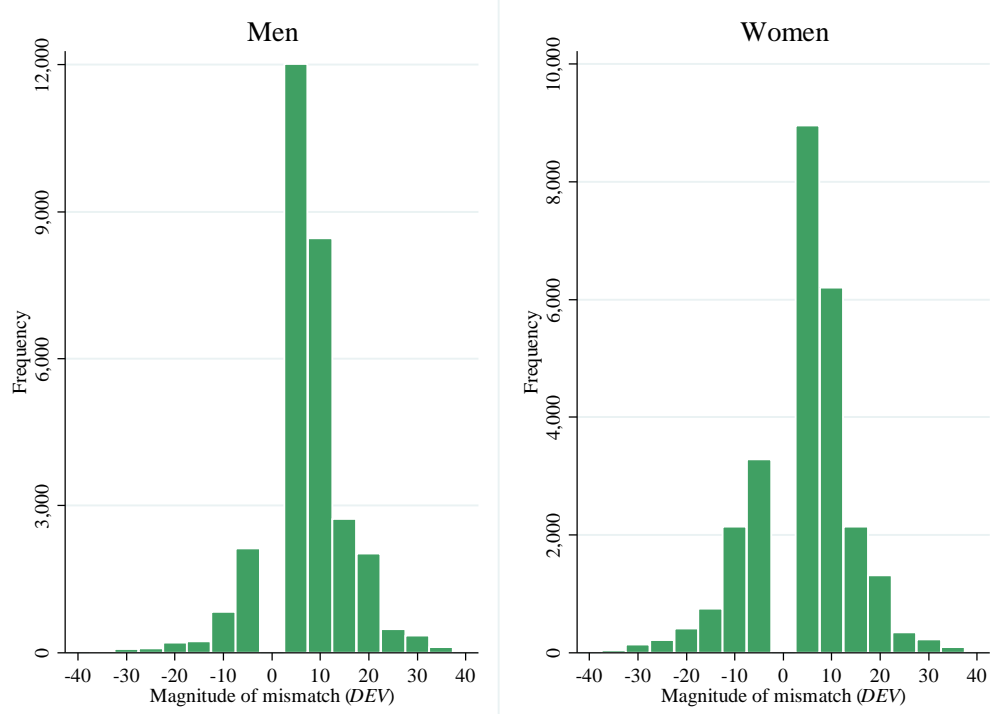

Notes: Distribution of the variable $D E V$ for constrained workers. The variable is rounded to steps of five.

Figure A.2: Overall distribution of mismatch variable

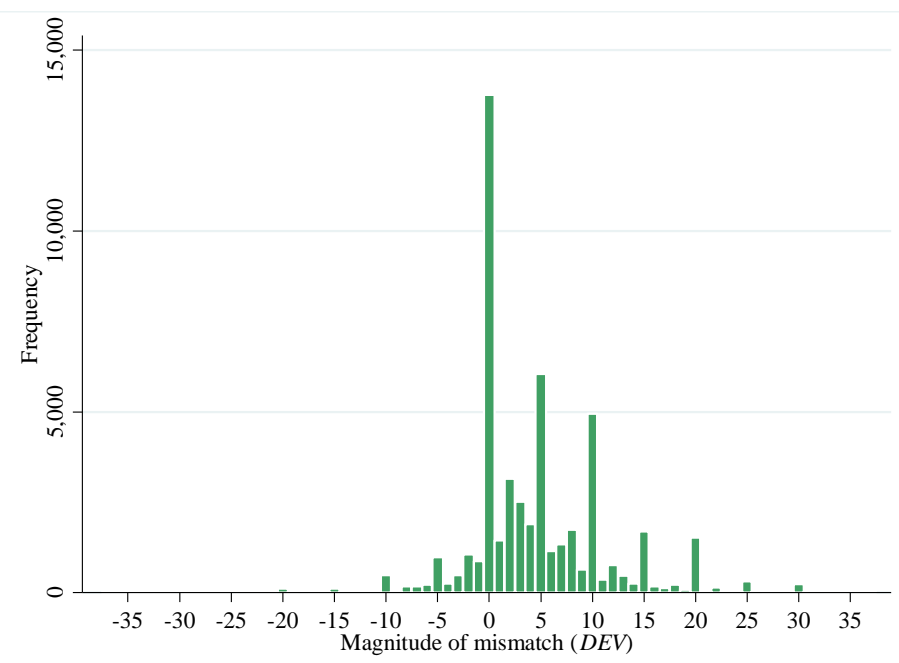

Notes: Histogram of $D E V$ in the whole sample. The width of the bars is set to one. 
Figure A.3: Distributions of actual and desired work hours

Hours distribution of underemployed in $\mathrm{t}$
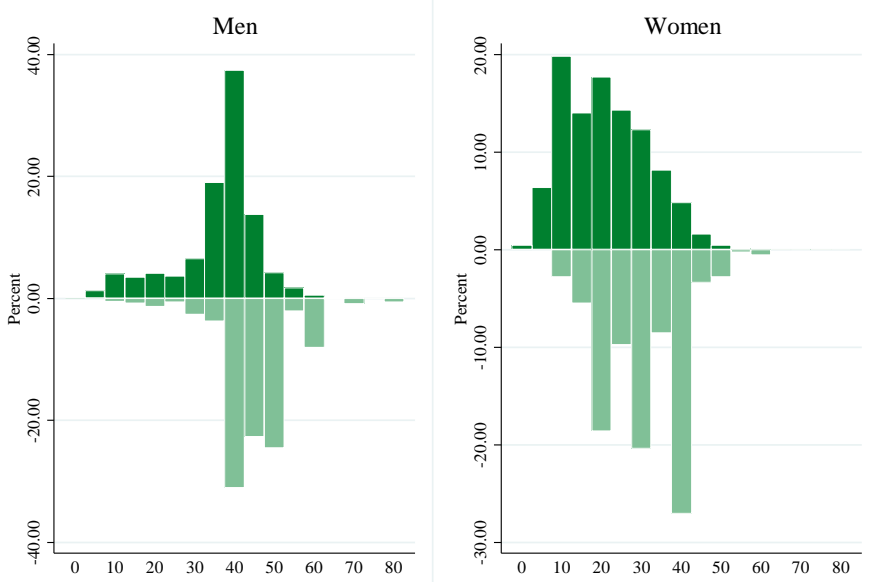

Hours distribution of overemployed in $\mathrm{t}$

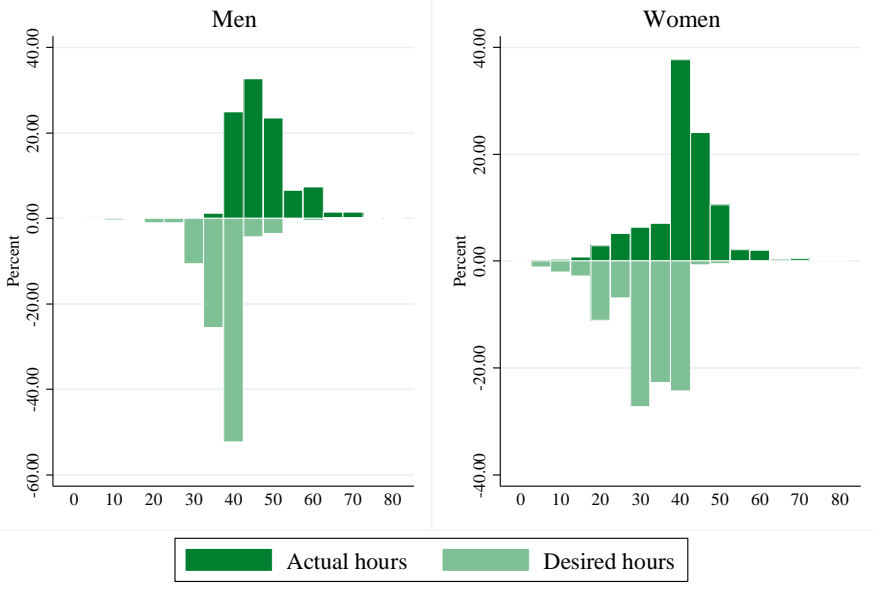

Notes: Bars have a width of five and are centered at steps of five. 
Table A.1: Differences between the three types of mismatches

\begin{tabular}{|c|c|c|c|c|c|c|}
\hline & \multicolumn{3}{|c|}{ Men } & \multicolumn{3}{|c|}{ Women } \\
\hline & Under & Uncon & Over & Under & Uncon & Over \\
\hline Magnitude of mismatch in $\mathrm{t}(D E V)$ & $-8.720 * * *$ & 0.282 & $9.432 * * *$ & $-9.632 * * *$ & 0.281 & $9.307 * * *$ \\
\hline Weekly actual hours (HA) & $36.156^{* * *}$ & 40.305 & $47.136 * * *$ & $21.045^{* * *}$ & 30.791 & $40.452 * * *$ \\
\hline Weekly desired hours (HD) & $44.876^{* * *}$ & 40.022 & $37.704^{* * *}$ & 30.677 & 30.51 & $31.144^{* * *}$ \\
\hline Hourly wage & $9.743^{* * *}$ & 10.505 & 10.583 & $7.700 * * *$ & 8.116 & 8.089 \\
\hline Job satisfaction & $6.832 * * *$ & 7.243 & $6.941^{* * *}$ & $6.855^{* * *}$ & 7.305 & $6.870^{* * *}$ \\
\hline Firm tenure & $7.900 * * *$ & 11.804 & $11.282^{* * *}$ & $6.880 * * *$ & 9.745 & $10.470 * * *$ \\
\hline Age & $36.801^{* * *}$ & 40.239 & $41.309 * * *$ & $40.310^{* * *}$ & 40.758 & 40.891 \\
\hline Fixed-term contract & $0.178 * * *$ & 0.094 & $0.065^{* * *}$ & $0.121^{* * *}$ & 0.1 & 0.099 \\
\hline Working overtime & 0.68 & 0.679 & $0.905^{* * *}$ & $0.520^{* * *}$ & 0.555 & $0.847^{* * *}$ \\
\hline Working overtime and compensated & 0.593 & 0.596 & $0.670^{* * *}$ & $0.466^{* * *}$ & 0.499 & $0.681^{* * *}$ \\
\hline In public service & 0.135 & 0.133 & $0.125^{* * *}$ & $0.164 * * *$ & 0.201 & $0.219 * * *$ \\
\hline Distance home to work & 24.696 & 23.118 & $30.051^{* * *}$ & $10.825^{* * *}$ & 13.396 & $17.767 * * *$ \\
\hline Firm over 200 employees & $0.471^{* * *}$ & 0.542 & $0.511^{* * *}$ & $0.312^{* * *}$ & 0.411 & $0.463^{* * *}$ \\
\hline Disabled & $0.041^{* * *}$ & 0.053 & $0.042 * * *$ & $0.030 * * *$ & 0.046 & 0.044 \\
\hline Homeowner & $0.387 * * *$ & 0.503 & $0.548^{* * *}$ & $0.490 * * *$ & 0.513 & 0.5 \\
\hline Health satisfaction & $7.023^{* * *}$ & 7.197 & $7.018^{* * *}$ & $6.949 * * *$ & 7.113 & $6.898^{* * *}$ \\
\hline Education in years & 11.999 & 12.042 & $12.862^{* * *}$ & $11.873^{* * *}$ & 12.203 & $12.985 * * *$ \\
\hline Monthly HH net income in 100 EUR & $26.873 * * *$ & 30.256 & $33.614^{* * *}$ & $27.348 * * *$ & 30.977 & $33.408^{* * *}$ \\
\hline Married & $0.539 * * *$ & 0.665 & $0.696^{* * *}$ & $0.699 * * *$ & 0.653 & $0.596^{* * *}$ \\
\hline Foreigner & $0.094 * * *$ & 0.108 & $0.062 * * *$ & 0.07 & 0.075 & $0.048^{* * *}$ \\
\hline Regional unemployment rate & $10.189 * * *$ & 9.578 & $9.799 * * *$ & $10.196^{* * *}$ & 9.916 & $10.750 * * *$ \\
\hline Living in a city & 0.451 & 0.453 & 0.46 & $0.405^{* * *}$ & 0.456 & 0.468 \\
\hline Living in a rural area & 0.251 & 0.234 & 0.238 & 0.265 & 0.252 & 0.261 \\
\hline East Germany & $0.248^{* * *}$ & 0.201 & $0.244^{* * *}$ & $0.249 * * *$ & 0.22 & $0.295^{* * *}$ \\
\hline Birth of a child & 0.041 & 0.032 & 0.032 & 0.004 & 0.005 & 0.005 \\
\hline No more person in need of care in $\mathrm{HH}$ & $0.008^{*}$ & 0.005 & 0.004 & 0.005 & 0.004 & 0.004 \\
\hline Divorced from $\mathrm{t}$ to $\mathrm{t}+1$ & 0.006 & 0.006 & 0.008 & $0.013^{* * *}$ & 0.009 & 0.007 \\
\hline Last child moved out & 0.03 & 0.032 & 0.031 & 0.035 & 0.033 & 0.032 \\
\hline Number of kids in $\mathrm{HH}$ & $0.725^{* * *}$ & 0.792 & 0.772 & $0.881^{* * *}$ & 0.66 & $0.467 * * *$ \\
\hline Single household & $0.151^{* * *}$ & 0.117 & 0.116 & $0.070 * * *$ & 0.097 & $0.123 * * *$ \\
\hline Observations & 3,586 & 21,208 & 26,165 & 6,986 & 19,290 & 19,275 \\
\hline
\end{tabular}

Notes: Means of the variables in the indicated groups are reported. * /** / *** indicate whether the differences between unconstrained and the two mismatch types are significance at a 10\% / 5\% / 1\% level. 
Table A.2: Only job quitters

\begin{tabular}{|c|c|c|c|c|c|c|c|c|}
\hline \multirow[b]{2}{*}{ Underemployed } & \multicolumn{4}{|c|}{ Men } & \multicolumn{4}{|c|}{ Women } \\
\hline & Movers & Stayers & Difference & S.E. & Movers & Stayers & Difference & S.E. \\
\hline$\Delta H A_{t+1}$ & 6.373 & 2.999 & $3.374 * * *$ & 1.043 & 8.331 & 2.255 & $6.076^{* * *}$ & 0.830 \\
\hline$\Delta H D_{t+1}$ & -2.701 & -3.563 & 0.862 & 0.931 & -0.885 & -2.425 & $1.540 * *$ & 0.683 \\
\hline$\Delta D E V_{t+1}$ & 9.074 & 6.562 & $2.512^{* *}$ & 1.155 & 9.217 & 4.681 & $4.536 * * *$ & 0.806 \\
\hline$O V E R_{t+1}$ & 0.299 & 0.192 & $0.107^{* *}$ & 0.054 & 0.260 & 0.109 & $0.151^{* * *}$ & 0.034 \\
\hline$U_{N C O N}{ }_{t+1}$ & 0.385 & 0.386 & -0.001 & 0.060 & 0.397 & 0.289 & $0.107 * * *$ & 0.041 \\
\hline$U N D E R_{t+1}$ & 0.316 & 0.422 & $-0.105 *$ & 0.059 & 0.343 & 0.602 & $-0.259 * * *$ & 0.041 \\
\hline Observations & 117 & 2,029 & & & 242 & 5,669 & & \\
\hline Overemployed & Movers & Stayers & Difference & S.E. & Movers & Stayers & Difference & S.E. \\
\hline$\Delta H A_{t+1}$ & -2.449 & -1.356 & $-1.093^{* *}$ & 0.433 & -3.310 & -1.309 & $-2.001^{* * *}$ & 0.501 \\
\hline$\Delta H D_{t+1}$ & 1.073 & 1.362 & -0.289 & 0.329 & 1.661 & 1.250 & 0.411 & 0.409 \\
\hline$\Delta D E V_{t+1}$ & -3.522 & -2.718 & $-0.803^{*}$ & 0.463 & -4.971 & -2.559 & $-2.412^{* * *}$ & 0.501 \\
\hline$O V E R_{t+1}$ & 0.697 & 0.729 & -0.033 & 0.025 & 0.560 & 0.714 & $-0.154^{* * *}$ & 0.031 \\
\hline$U_{N C O N}{ }_{t+1}$ & 0.263 & 0.235 & 0.028 & 0.024 & 0.344 & 0.236 & $0.108 * * *$ & 0.029 \\
\hline$U N D E R_{t+1}$ & 0.041 & 0.035 & 0.005 & 0.011 & 0.096 & 0.050 & $0.046^{* * *}$ & 0.017 \\
\hline Observations & 567 & 21,016 & & & 407 & 15,049 & & \\
\hline
\end{tabular}

Notes: Standard errors are based on 4999 bootstrap replications. The bootstraps are clustered on individual level. $*$ / ** / *** indicate significance at a $10 \% / 5 \% / 1 \%$ level.

Table A.3: Job changes for external reasons

\begin{tabular}{|c|c|c|c|c|c|c|c|c|}
\hline \multirow[b]{2}{*}{ Underemployed } & \multicolumn{4}{|c|}{ Men } & \multicolumn{4}{|c|}{ Women } \\
\hline & Movers & Stayers & Difference & S.E. & Movers & Stayers & Difference & S.E. \\
\hline$\Delta H A_{t+1}$ & 8.214 & 3.582 & $4.632 * * *$ & 1.055 & 7.587 & 2.734 & $4.852^{* * *}$ & 0.871 \\
\hline$\Delta H D_{t+1}$ & -2.486 & -3.836 & $1.351^{*}$ & 0.812 & -0.575 & -2.539 & $1.964 * * *$ & 0.605 \\
\hline$\Delta D E V_{t+1}$ & 10.700 & 7.418 & $3.282^{* * *}$ & 1.067 & 8.162 & 5.273 & $2.889 * * *$ & 0.809 \\
\hline$O V E R_{t+1}$ & 0.354 & 0.189 & $0.165^{* * *}$ & 0.047 & 0.255 & 0.130 & $0.125^{* * *}$ & 0.032 \\
\hline$U_{N C O N} t_{t+1}$ & 0.333 & 0.373 & -0.040 & 0.050 & 0.358 & 0.258 & $0.100^{* * *}$ & 0.038 \\
\hline$U N D E R_{t+1}$ & 0.312 & 0.438 & $-0.126^{* *}$ & 0.050 & 0.387 & 0.612 & $-0.226^{* * *}$ & 0.039 \\
\hline Observations & 189 & 2,889 & & & 282 & 5,724 & & \\
\hline Overemployed & Movers & Stayers & Difference & S.E. & Movers & Stayers & Difference & S.E. \\
\hline$\Delta H A_{t+1}$ & -3.926 & -1.696 & $-2.229 * * *$ & 0.409 & -4.767 & -1.263 & $-3.504 * * *$ & 0.521 \\
\hline$\Delta H D_{t+1}$ & 1.077 & 0.932 & 0.145 & 0.300 & 1.404 & 1.300 & 0.104 & 0.372 \\
\hline$\Delta D E V_{t+1}$ & -5.002 & -2.628 & $-2.374^{* * *}$ & 0.423 & -6.171 & -2.563 & $-3.608^{* * *}$ & 0.497 \\
\hline$O V E R_{t+1}$ & 0.618 & 0.753 & $-0.135^{* * *}$ & 0.023 & 0.541 & 0.706 & $-0.165^{* * *}$ & 0.027 \\
\hline $\operatorname{UNCON}_{t+1}$ & 0.293 & 0.208 & $0.085^{* * *}$ & 0.021 & 0.299 & 0.246 & $0.053 * *$ & 0.024 \\
\hline$U_{N D E R_{t+1}}$ & 0.089 & 0.040 & $0.050^{* * *}$ & 0.013 & 0.160 & 0.048 & $0.112^{* * *}$ & 0.017 \\
\hline Observations & 772 & 22,776 & & & 556 & 16,506 & & \\
\hline
\end{tabular}

Notes: As external reasons are considered: Plant closure, lay-off, dissolution contracts and ending of fixed-term contracts. Standard errors are based on 4999 bootstrap replications. The bootstraps are clustered on individual level. * / ** / *** indicate significance at a 10\% / 5\% / 1\% level. 
Table A,4: Job changes across employers

\begin{tabular}{|c|c|c|c|c|c|c|c|c|}
\hline \multirow[b]{2}{*}{ Underemployed } & \multicolumn{4}{|c|}{ Men } & \multicolumn{4}{|c|}{ Women } \\
\hline & Movers & Stayers & Difference & S.E. & Movers & Stayers & Difference & S.E. \\
\hline$\Delta H A_{t+1}$ & 8.410 & 4.318 & $4.092 * * *$ & 0.706 & 8.949 & 2.594 & $6.355^{* * *}$ & 0.522 \\
\hline$\Delta H D_{t+1}$ & -2.745 & -3.939 & $1.194^{* *}$ & 0.528 & -0.601 & -2.830 & $2.229 * * *$ & 0.403 \\
\hline$\Delta D E V_{t+1}$ & 11.155 & 8.257 & $2.898 * * *$ & 0.731 & 9.550 & 5.424 & $4.126^{* * *}$ & 0.511 \\
\hline OVER $_{t+1}$ & 0.327 & 0.226 & $0.102 * * *$ & 0.029 & 0.254 & 0.126 & $0.128^{* * *}$ & 0.020 \\
\hline$U_{N C O N}{ }_{t+1}$ & 0.381 & 0.356 & 0.025 & 0.033 & 0.379 & 0.271 & $0.107^{* * *}$ & 0.023 \\
\hline$U N D E R_{t+1}$ & 0.292 & 0.419 & $-0.126^{* * *}$ & 0.033 & 0.368 & 0.602 & $-0.235^{* * *}$ & 0.024 \\
\hline Observations & 452 & 2,363 & & & 819 & 6,087 & & \\
\hline Overemployed & Movers & Stayers & Difference & S.E. & Movers & Stayers & Difference & S.E. \\
\hline$\Delta H A_{t+1}$ & -3.145 & -1.521 & $-1.624 * * *$ & 0.275 & -4.205 & -1.600 & $-2.606^{* * *}$ & 0.351 \\
\hline$\Delta H D_{t+1}$ & 1.002 & 0.935 & 0.066 & 0.219 & 1.314 & 1.436 & -0.123 & 0.256 \\
\hline$\Delta D E V_{t+1}$ & -4.147 & -2.457 & $-1.690^{* * *}$ & 0.296 & -5.519 & -3.036 & $-2.483^{* * *}$ & 0.330 \\
\hline$O V E R_{t+1}$ & 0.648 & 0.745 & $-0.098 * * *$ & 0.017 & 0.552 & 0.699 & $-0.147^{* * *}$ & 0.019 \\
\hline$U_{N C O N}{ }_{t+1}$ & 0.281 & 0.221 & $0.060 * * *$ & 0.015 & 0.311 & 0.244 & $0.067 * * *$ & 0.018 \\
\hline$U N D E R_{t+1}$ & 0.071 & 0.034 & $0.037 * * *$ & 0.009 & 0.137 & 0.057 & $0.080 * * *$ & 0.012 \\
\hline Observations & 1,627 & 23,893 & & & 1,186 & 17,692 & & \\
\hline
\end{tabular}

Notes: Standard errors are based on 4999 bootstrap replications. The bootstraps are clustered on individual level. * / ** / *** indicate significance at a $10 \% / 5 \%$ / $1 \%$ level.

Table A.5: Job changes within same employer

\begin{tabular}{|c|c|c|c|c|c|c|c|c|}
\hline \multirow[b]{2}{*}{ Underemployed } & \multicolumn{4}{|c|}{ Men } & \multicolumn{4}{|c|}{ Women } \\
\hline & Movers & Stayers & Difference & S.E. & Movers & Stayers & Difference & S.E. \\
\hline$\Delta H A_{t+1}$ & 9.168 & 4.561 & $4.606^{* * *}$ & 1.714 & 10.942 & 3.722 & $7.220 * * *$ & 1.248 \\
\hline$\Delta H D_{t+1}$ & -1.854 & -2.971 & 1.117 & 1.176 & -0.806 & -2.008 & 1.202 & 0.981 \\
\hline$\Delta D E V_{t+1}$ & 11.022 & 7.532 & $3.489 * *$ & 1.695 & 11.748 & 5.730 & $6.018^{* * *}$ & 1.153 \\
\hline$O V E R_{t+1}$ & 0.369 & 0.198 & $0.171^{* *}$ & 0.074 & 0.398 & 0.181 & $0.216^{* * *}$ & 0.059 \\
\hline$U N C O N_{t+1}$ & 0.338 & 0.411 & -0.073 & 0.082 & 0.409 & 0.295 & $0.113^{*}$ & 0.067 \\
\hline$U N D E R_{t+1}$ & 0.292 & 0.390 & -0.098 & 0.079 & 0.194 & 0.523 & $-0.330 * * *$ & 0.062 \\
\hline Observations & 65 & 1,582 & & & 93 & 5,256 & & \\
\hline Overemployed & Movers & Stayers & Difference & S.E. & Movers & Stayers & Difference & S.E. \\
\hline$\Delta H A_{t+1}$ & -1.130 & -1.212 & 0.082 & 0.533 & -1.193 & -1.156 & -0.037 & 0.508 \\
\hline$\Delta H D_{t+1}$ & 1.599 & 1.069 & 0.531 & 0.406 & 1.647 & 1.356 & 0.290 & 0.453 \\
\hline$\Delta D E V_{t+1}$ & -2.729 & -2.280 & -0.449 & 0.522 & -2.839 & -2.512 & -0.327 & 0.547 \\
\hline$O V E R_{t+1}$ & 0.735 & 0.762 & -0.026 & 0.032 & 0.686 & 0.746 & $-0.060^{*}$ & 0.032 \\
\hline$U N C O N_{t+1}$ & 0.232 & 0.210 & 0.023 & 0.031 & 0.258 & 0.223 & 0.034 & 0.031 \\
\hline$U N D E R_{t+1}$ & 0.032 & 0.029 & 0.004 & 0.012 & 0.056 & 0.031 & 0.025 & 0.015 \\
\hline Observations & 340 & 22,570 & & & 322 & 17,482 & & \\
\hline
\end{tabular}

Notes: Standard errors are based on 4999 bootstrap replications. The bootstraps are clustered on individual level. $*$ / ** / *** indicate significance at a $10 \% / 5 \% / 1 \%$ level. 
Table A.6: Job changes more than three months after the interview in $t$

\begin{tabular}{|c|c|c|c|c|c|c|c|c|}
\hline \multirow[b]{2}{*}{ Underemployed } & \multicolumn{4}{|c|}{ Men } & \multicolumn{4}{|c|}{ Women } \\
\hline & Movers & Stayers & Difference & S.E. & Movers & Stayers & Difference & S.E. \\
\hline$\Delta H A_{t+1}$ & 8.501 & 3.692 & $4.809 * * *$ & 0.783 & 8.966 & 2.793 & $6.173^{* * *}$ & 0.558 \\
\hline$\Delta H D_{t+1}$ & -2.466 & -4.146 & $1.680 * * *$ & 0.621 & -0.668 & -2.604 & $1.936 * * *$ & 0.449 \\
\hline$\Delta D E V_{t+1}$ & 10.967 & 7.839 & $3.129 * * *$ & 0.816 & 9.634 & 5.397 & $4.237 * * *$ & 0.540 \\
\hline$O V E R_{t+1}$ & 0.317 & 0.207 & $0.110 * * *$ & 0.033 & 0.274 & 0.132 & $0.142 * * *$ & 0.022 \\
\hline$U_{N C O N}{ }_{t+1}$ & 0.387 & 0.353 & 0.034 & 0.035 & 0.374 & 0.261 & $0.113^{* * *}$ & 0.026 \\
\hline$U N D E R_{t+1}$ & 0.296 & 0.440 & $-0.144^{* * *}$ & 0.037 & 0.353 & 0.607 & $-0.254^{* * *}$ & 0.026 \\
\hline Observations & 372 & 2,583 & & & 658 & 5,972 & & \\
\hline Overemployed & Movers & Stayers & Difference & S.E. & Movers & Stayers & Difference & S.E. \\
\hline$\Delta H A_{t+1}$ & -3.094 & -1.341 & $-1.752^{* * *}$ & 0.297 & -3.611 & -1.421 & $-2.191 * * *$ & 0.348 \\
\hline$\Delta H D_{t+1}$ & 1.077 & 1.120 & -0.043 & 0.225 & 1.269 & 1.388 & -0.119 & 0.267 \\
\hline$\Delta D E V_{t+1}$ & -4.171 & -2.461 & $-1.709 * * *$ & 0.303 & -4.880 & -2.809 & $-2.072^{* * *}$ & 0.340 \\
\hline$O V E R_{t+1}$ & 0.653 & 0.726 & $-0.073 * * *$ & 0.017 & 0.577 & 0.705 & $-0.128 * * *$ & 0.019 \\
\hline$U_{N C O N}{ }_{t+1}$ & 0.275 & 0.239 & $0.036^{* *}$ & 0.016 & 0.298 & 0.237 & $0.062 * * *$ & 0.018 \\
\hline$U N D E R_{t+1}$ & 0.072 & 0.035 & $0.037 * * *$ & 0.009 & 0.125 & 0.058 & $0.067 * * *$ & 0.012 \\
\hline Observations & 1,398 & 23,765 & & & 1,090 & 17,708 & & \\
\hline
\end{tabular}

Notes: Standard errors are based on 4999 bootstrap replications. The bootstraps are clustered on individual level. * / **/*** indicate significance at a $10 \% / 5 \%$ / $1 \%$ level.

Table A.7: Re-definition of unconstrained: $\mathrm{UNCON}_{\text {it }}$ if $\left|\mathrm{DEV}_{\mathrm{it}}\right|<5$

\begin{tabular}{|c|c|c|c|c|c|c|c|c|}
\hline \multirow[b]{2}{*}{ Underemployed } & \multicolumn{4}{|c|}{ Men } & \multicolumn{4}{|c|}{ Women } \\
\hline & Movers & Stayers & Difference & S.E. & Movers & Stayers & Difference & S.E. \\
\hline$\Delta H A_{t+1}$ & 9.277 & 4.871 & $4.407 * * *$ & 0.757 & 9.873 & 3.055 & $6.818^{* * *}$ & 0.541 \\
\hline$\Delta H D_{t+1}$ & -3.179 & -3.973 & 0.794 & 0.566 & -0.941 & -3.135 & $2.194^{* * *}$ & 0.421 \\
\hline$\Delta D E V_{t+1}$ & 12.457 & 8.844 & $3.613^{* * *}$ & 0.777 & 10.814 & 6.190 & $4.623^{* * *}$ & 0.519 \\
\hline$O V E R_{t+1}$ & 0.311 & 0.179 & $0.132 * * *$ & 0.029 & 0.239 & 0.104 & $0.135^{* * *}$ & 0.019 \\
\hline$U_{N C O N}{ }_{t+1}$ & 0.414 & 0.399 & 0.015 & 0.034 & 0.436 & 0.329 & $0.106^{* * *}$ & 0.025 \\
\hline$U N D E R_{t+1}$ & 0.275 & 0.422 & $-0.147^{* * *}$ & 0.033 & 0.326 & 0.567 & $-0.241 * * *$ & 0.024 \\
\hline Observations & 440 & 2,306 & & & 792 & 5,114 & & \\
\hline Overemployed & Movers & Stayers & Difference & S.E. & Movers & Stayers & Difference & S.E. \\
\hline$\Delta H A_{t+1}$ & -3.229 & -1.782 & $-1.447^{* * *}$ & 0.272 & -4.013 & -1.783 & $-2.230 * * *$ & 0.320 \\
\hline$\Delta H D_{t+1}$ & 1.216 & 1.258 & -0.042 & 0.200 & 1.643 & 1.621 & 0.021 & 0.246 \\
\hline$\Delta D E V_{t+1}$ & -4.444 & -3.039 & $-1.405^{* * *}$ & 0.287 & -5.656 & -3.404 & $-2.252^{* * *}$ & 0.316 \\
\hline$O V E R_{t+1}$ & 0.619 & 0.702 & $-0.083^{* * *}$ & 0.016 & 0.533 & 0.665 & $-0.132 * * *$ & 0.018 \\
\hline$U_{N C O N}{ }_{t+1}$ & 0.328 & 0.268 & $0.060 * * *$ & 0.015 & 0.367 & 0.299 & $0.068 * * *$ & 0.018 \\
\hline$U N D E R_{t+1}$ & 0.054 & 0.031 & $0.023^{* * *}$ & 0.007 & 0.100 & 0.036 & $0.064^{* * *}$ & 0.010 \\
\hline Observations & 1,728 & 20,715 & & & 1,281 & 14,749 & & \\
\hline
\end{tabular}

Notes: Standard errors are based on 4999 bootstrap replications. The bootstraps are clustered on individual level. * / ** / *** indicate significance at a $10 \%$ / $5 \%$ / $1 \%$ level. 
Table A.8: Main results for the sample with 4 time periods

\begin{tabular}{|c|c|c|c|c|c|c|c|c|}
\hline \multirow[b]{2}{*}{ Underemployed } & \multicolumn{4}{|c|}{ Men } & \multicolumn{4}{|c|}{ Women } \\
\hline & Movers & Stayers & Difference & S.E. & Movers & Stayers & Difference & S.E. \\
\hline$\Delta H A_{t+1}$ & 8.706 & 3.729 & $4.977^{* * *}$ & 1.047 & 9.262 & 3.392 & $5.870 * * *$ & 0.676 \\
\hline$\Delta H D_{t+1}$ & -1.971 & -3.666 & $1.695 * *$ & 0.734 & -0.497 & -2.095 & $1.598 * * *$ & 0.523 \\
\hline$\Delta D E V_{t+1}$ & 10.677 & 7.394 & $3.282 * * *$ & 1.093 & 9.760 & 5.487 & $4.272 * * *$ & 0.620 \\
\hline$O V E R_{t+1}$ & 0.341 & 0.200 & $0.141^{* * *}$ & 0.044 & 0.273 & 0.120 & $0.153^{* * *}$ & 0.027 \\
\hline$U_{N C O N}{ }_{t+1}$ & 0.380 & 0.398 & -0.018 & 0.046 & 0.414 & 0.299 & $0.115^{* * *}$ & 0.034 \\
\hline$U N D E R_{t+1}$ & 0.278 & 0.402 & $-0.124 * *$ & 0.048 & 0.313 & 0.582 & $-0.269 * * *$ & 0.034 \\
\hline Observations & 202 & 1,668 & & & 377 & 3,405 & & \\
\hline Overemployed & Movers & Stayers & Difference & S.E. & Movers & Stayers & Difference & S.E. \\
\hline$\Delta H A_{t+1}$ & -2.226 & -0.952 & $-1.274^{* * *}$ & 0.295 & -2.874 & -1.451 & $-1.423^{* * *}$ & 0.391 \\
\hline$\Delta H D_{t+1}$ & 1.201 & 0.870 & 0.332 & 0.248 & 1.326 & 1.346 & -0.020 & 0.312 \\
\hline$\Delta D E V_{t+1}$ & -3.427 & -1.822 & $-1.606^{* * *}$ & 0.319 & -4.200 & -2.797 & $-1.403^{* * *}$ & 0.394 \\
\hline$O V E R_{t+1}$ & 0.677 & 0.774 & $-0.097 * * *$ & 0.019 & 0.626 & 0.722 & $-0.096 * * *$ & 0.023 \\
\hline$U_{N C O N}{ }_{t+1}$ & 0.274 & 0.203 & $0.071^{* * *}$ & 0.018 & 0.281 & 0.226 & $0.055^{* * *}$ & 0.021 \\
\hline$U N D E R_{t+1}$ & 0.049 & 0.023 & $0.026^{* * *}$ & 0.008 & 0.093 & 0.053 & $0.041^{* * *}$ & 0.014 \\
\hline Observations & 1,077 & 15,737 & & & 730 & 11,171 & & \\
\hline
\end{tabular}

Notes: Standard errors are based on 4999 bootstrap replications. The bootstraps are clustered on individual level. * / ** / *** indicate significance at a $10 \% / 5 \% / 1 \%$ level. 


\section{Further Appendices}

\section{B: Data preparation}

Table B.1: Steps of data preparation

\begin{tabular}{lr}
\hline No. of obs. with reported actual and desired work hours & 173,017 \\
- younger 20 & $-3,974$ \\
- older 59 & $-10,403$ \\
- self-employed & $-13,803$ \\
- second job holders & $-5,152$ \\
\hline Raw sample & 139,685 \\
- not employed / observed in two subsequent periods & $-38,069$ \\
- missing values in control variables & $-4,642$ \\
- absolute mismatch $(|\mathrm{DEV}|) \geq 37.5$ (common support) & -464 \\
\hline Final sample & 96,510 \\
\hline
\end{tabular}


Table B.2: Descriptive statistics for kept and dropped workers

\begin{tabular}{|c|c|c|c|c|}
\hline & \multicolumn{2}{|c|}{ Men } & \multicolumn{2}{|c|}{ Women } \\
\hline & Sample & Dropped & Sample & Dropped \\
\hline Overemployed & $0.513^{* * *}$ & 0.482 & $0.423^{* * *}$ & 0.382 \\
\hline Unconstrained & $0.416^{* * *}$ & 0.394 & $0.423^{* * *}$ & 0.404 \\
\hline Underemployed & $0.070 * * *$ & 0.124 & $0.153 * * *$ & 0.214 \\
\hline Job change from $t$ to $t+1$ & $0.079 * * *$ & 0.17 & $0.082^{* * *}$ & 0.168 \\
\hline Magnitude of mismatch in $\mathrm{t}(\mathrm{DEV})$ & $4.347 * * *$ & 3.798 & $2.580 * * *$ & 1.479 \\
\hline Weekly actual hours & $43.520 * * *$ & 42.107 & $33.384 * * *$ & 31.268 \\
\hline Weekly desired hours & $39.173 * * *$ & 38.308 & $30.804 * * *$ & 29.789 \\
\hline Hourly wage & $10.492 * * *$ & 9.7 & $8.041^{* * *}$ & 7.74 \\
\hline Job satisfaction & $7.059 * * *$ & 6.916 & $7.052 * * *$ & 6.925 \\
\hline Firm tenure & $11.261^{* * *}$ & 10.071 & $9.612 * * *$ & 8.339 \\
\hline Age & $40.546 * * *$ & 40.058 & $40.746^{* * *}$ & 39.985 \\
\hline Fixed-term contract & $0.085^{* * *}$ & 0.174 & $0.103^{* * *}$ & 0.176 \\
\hline Working overtime & $0.795 * * *$ & 0.721 & $0.673 * * *$ & 0.597 \\
\hline Working overtime and compensated & $0.634 * * *$ & 0.57 & $0.571^{* * *}$ & 0.499 \\
\hline In public service & $0.129 * * *$ & 0.112 & $0.203 * * *$ & 0.171 \\
\hline Distance home to work & $26.789 *$ & 27.783 & 14.851 & 15.118 \\
\hline Firm over 200 employees & $0.521 * * *$ & 0.45 & $0.418^{* * *}$ & 0.374 \\
\hline Disabled & $0.046^{* * *}$ & 0.063 & $0.043^{* * *}$ & 0.05 \\
\hline Homeowner & $0.518^{* * *}$ & 0.491 & $0.504 * * *$ & 0.474 \\
\hline Health satisfaction & $7.093 * * *$ & 6.543 & $6.997 * * *$ & 6.501 \\
\hline Education in years & $12.460 * * *$ & 12.287 & $12.483^{* * *}$ & 12.355 \\
\hline Monthly HH net income in 100 EUR & $31.742 * * *$ & 28.218 & $31.449 * * *$ & 25.862 \\
\hline Married & $0.672^{* * *}$ & 0.575 & $0.636 * * *$ & 0.584 \\
\hline Foreigner & $0.083 * * *$ & 0.092 & $0.063 * * *$ & 0.078 \\
\hline Regional unemployment rate & $9.734 * * *$ & 9.211 & $10.312^{* * *}$ & 9.235 \\
\hline Living in a city & $0.456 * * *$ & 0.444 & 0.453 & 0.444 \\
\hline Living in a rural area & $0.237 * * *$ & 0.251 & 0.258 & 0.255 \\
\hline East Germany & 0.226 & 0.233 & $0.256 * * *$ & 0.226 \\
\hline Birth of a child & $0.032 * * *$ & 0.014 & $0.005^{* * *}$ & 0.068 \\
\hline No more person in need of care in hh & $0.005^{* * *}$ & 0.001 & $0.004^{* * *}$ & 0.001 \\
\hline Divorced from $t$ to $t+1$ & $0.007 * * *$ & 0.001 & $0.009 * * *$ & 0.001 \\
\hline Last child moved out & $0.031 * * *$ & 0.004 & $0.033^{* * *}$ & 0.004 \\
\hline Observations & 50,959 & 21,220 & 45,551 & 21,955 \\
\hline
\end{tabular}

Notes: Means of the variables in the indicated groups are reported. * / ** / *** indicate whether the differences between kept and dropped workers are significance at a $10 \%$ / 5\% / $1 \%$ level. 


\section{C: Propensity score}

Table C.1: Propensity score estimates

\begin{tabular}{|c|c|c|c|c|}
\hline & \multicolumn{2}{|c|}{ Underemployed } & \multicolumn{2}{|c|}{ Overemployed } \\
\hline & Men & Women & Men & Women \\
\hline Firm tenure & $-0.012 * * *$ & $-0.014^{* * *}$ & $-0.008 * * *$ & $-0.007 * * *$ \\
\hline Firm tenure squared & $0.000 * * *$ & $0.000 * * *$ & $0.000 * * *$ & $0.000 * * *$ \\
\hline Job satisfaction & $-0.032 * * *$ & $-0.032 * * *$ & $-0.015^{* * *}$ & $-0.021 * * *$ \\
\hline Job satisfaction squared & 0.001 & $0.001^{* *}$ & 0.000 & $0.001 * *$ \\
\hline Log hourly wage & -0.015 & $-0.052 * * *$ & $-0.028 * * *$ & $-0.016 * * *$ \\
\hline Fixed-term contract & $0.065 * * *$ & $0.071 * * *$ & $0.047 * * *$ & $0.059 * * *$ \\
\hline Working overtime & -0.011 & 0.006 & $0.012 *$ & 0.006 \\
\hline Working overtime and compensated & -0.009 & $-0.028 *$ & $-0.010 * *$ & -0.005 \\
\hline In public service & -0.012 & -0.0184 & -0.008 & $-0.010^{*}$ \\
\hline Distance to work over $20 \mathrm{~km}$ & 0.017 & 0.015 & $0.021 * * *$ & $0.017 * * *$ \\
\hline$H A_{t}$ & -0.003 & $-0.006 * * *$ & -0.002 & 0.001 \\
\hline$H A_{t}$ squared & 0.000 & $0.000 * * *$ & 0.000 & -0.000 \\
\hline Firm over 200 employees & $-0.023 * *$ & -0.008 & -0.005 & -0.003 \\
\hline Disabled & -0.053 & 0.013 & -0.008 & -0.017 \\
\hline Homeowner & 0.006 & -0.000 & $-0.010 * * *$ & $-0.009 * *$ \\
\hline Health satisfaction & $0.007 * *$ & $0.004 * *$ & $0.005^{* * *}$ & $0.004 * * *$ \\
\hline Education in years & 0.000 & 0.003 & 0.001 & $0.003^{* * *}$ \\
\hline Log monthly HH net income & 0.004 & $0.017^{* *}$ & $0.009 * *$ & 0.000 \\
\hline Married & $-0.024^{*}$ & $-0.041^{* * *}$ & $0.009 * *$ & 0.002 \\
\hline Foreigner & -0.020 & -0.015 & -0.008 & $-0.018^{*}$ \\
\hline Regional unemployment rate & -0.004 & 0.001 & 0.001 & 0.001 \\
\hline Living in a city & -0.008 & -0.002 & -0.001 & $0.014^{* * *}$ \\
\hline Living in a rural area & $-0.026^{*}$ & 0.006 & -0.003 & 0.001 \\
\hline East Germany & 0.023 & -0.026 & -0.011 & $-0.017^{*}$ \\
\hline Birth of a child & 0.005 & 0.035 & 0.004 & 0.030 \\
\hline No more person in need of care in $\mathrm{HH}$ & 0.067 & $0.119 * *$ & -0.025 & -0.020 \\
\hline Divorced from $t$ to $t+1$ & -0.066 & $0.086^{* * *}$ & 0.018 & -0.017 \\
\hline Last child moved out & -0.012 & -0.003 & 0.006 & $0.019 * *$ \\
\hline$\left|D E V_{t}\right|$ rounded to 5 & \multicolumn{4}{|c|}{ Reference categorie } \\
\hline$\left|D E V_{t}\right|$ rounded to 10 & $0.023^{*}$ & 0.008 & 0.004 & 0.004 \\
\hline$\left|D E V_{t}\right|$ rounded to 15 & 0.002 & 0.020 & 0.003 & 0.003 \\
\hline$\left|D E V_{t}\right|$ rounded to 20 & $0.036^{*}$ & 0.013 & -0.002 & $0.016^{*}$ \\
\hline$\left|D E V_{t}\right|$ rounded to 25 & $0.105^{* *}$ & $0.038 *$ & $-0.022 * *$ & -0.016 \\
\hline$\left|D E V_{t}\right|$ rounded to 30 & 0.032 & 0.037 & -0.011 & -0.017 \\
\hline$\left|D E V_{t}\right|$ rounded to 35 & -0.007 & $0.090 *$ & -0.015 & -0.011 \\
\hline Age categorie 20-24 & \multicolumn{4}{|c|}{ Reference categorie } \\
\hline Age categorie 25-29 & 0.006 & 0.004 & 0.001 & $-0.031 * * *$ \\
\hline Age categorie 30-34 & -0.005 & -0.026 & -0.016 & $-0.031 * * *$ \\
\hline Age categorie 35-39 & $-0.043^{*}$ & $-0.043^{* *}$ & $-0.018 *$ & $-0.045^{* * *}$ \\
\hline Age categorie 40-44 & -0.035 & $-0.072 * * *$ & $-0.028 * * *$ & $-0.050 * * *$ \\
\hline Age categorie 45-49 & $-0.056^{* *}$ & $-0.068 * * *$ & $-0.038 * * *$ & $-0.057 * * *$ \\
\hline
\end{tabular}

Table continued on the next page. 
Table continued

\begin{tabular}{|c|c|c|c|c|}
\hline Age categorie 50-54 & $-0.109 * * *$ & $-0.085^{* * *}$ & $-0.048 * * *$ & $-0.072 * * *$ \\
\hline Age categorie 50-59 & $-0.085 * * *$ & $-0.145^{* * *}$ & $-0.055^{* * *}$ & $-0.081 * * *$ \\
\hline Year 1997 & 0.028 & $-0.044 *$ & $-0.017 * *$ & -0.015 \\
\hline Year 1998 & -0.037 & $-0.046 * *$ & -0.005 & -0.014 \\
\hline Year 1999 & -0.009 & -0.016 & -0.004 & -0.006 \\
\hline Year 2000 & \multicolumn{4}{|c|}{ Reference categorie } \\
\hline Year 2001 & -0.029 & -0.013 & -0.002 & $-0.022 * *$ \\
\hline Year 2002 & -0.011 & -0.030 & $-0.018 * *$ & -0.007 \\
\hline Year 2003 & $-0.052 * *$ & $-0.072 * * *$ & $-0.020 * *$ & $-0.027 * * *$ \\
\hline Year 2004 & -0.004 & $-0.068 * * *$ & $-0.015 *$ & -0.015 \\
\hline Year 2005 & -0.026 & $-0.057 * * *$ & $-0.024 * * *$ & $-0.035 * * *$ \\
\hline Year 2006 & -0.024 & $-0.063 * * *$ & $-0.016 * *$ & -0.010 \\
\hline Year 2007 & -0.039 & $-0.040^{* *}$ & -0.004 & -0.013 \\
\hline Year 2008 & -0.016 & -0.032 & -0.005 & 0.003 \\
\hline Year 2009 & -0.012 & -0.013 & $-0.017 * *$ & -0.011 \\
\hline Year 2010 & -0.018 & -0.014 & -0.010 & 0.002 \\
\hline Year 2011 & 0.006 & -0.022 & -0.006 & 0.004 \\
\hline Managers & \multicolumn{4}{|c|}{ Reference categorie } \\
\hline Armed forces occupations & -0.024 & - & -0.013 & - \\
\hline Professionals & $0.057^{*}$ & -0.007 & -0.008 & -0.005 \\
\hline Technicians and associate professionals & 0.029 & -0.030 & -0.010 & -0.012 \\
\hline Clerical support workers & 0.001 & -0.052 & -0.008 & -0.007 \\
\hline Service and sales workers & 0.032 & -0.034 & -0.006 & 0.006 \\
\hline Agricultural forestry and fishery workers & -0.006 & 0.043 & $-0.053 * * *$ & 0.033 \\
\hline Craft and related trades workers & 0.014 & -0.038 & $-0.014^{*}$ & -0.010 \\
\hline Plant and machine operators and assemblers & 0.015 & -0.073 & $-0.023 * * *$ & $-0.026^{*}$ \\
\hline Elementary occupations & 0.034 & -0.045 & $-0.027 * * *$ & -0.004 \\
\hline Observations & 3,586 & 6,986 & 26,165 & 19,275 \\
\hline Pseudo R-squared & 0.199 & 0.180 & 0.134 & 0.156 \\
\hline
\end{tabular}

Notes: Average marginal effects. Inference based in 4999 bootstrap replications. $*$ / ** / *** indicate significance at a $10 \%$ / 5\% / 1\% level. 


\section{D: Common Support}

Propensity score matching requires common support of the propensity score for movers and stayers.

Figure D.1 below depicts the corresponding distributions. We follow Lechner and Strittmatter (2014) and remove observations that are off-support. This leads to only 9 observations being removed over all subsamples. This indicates that our application faces no common support problem. However, when zooming into the right tail of the distributions, the support gets rather thin. As a robustness check we exclude all observations above 0.6, which does not affect our results, as we can see in Table D.1.

Figure D.1: Distribution of the propensity score
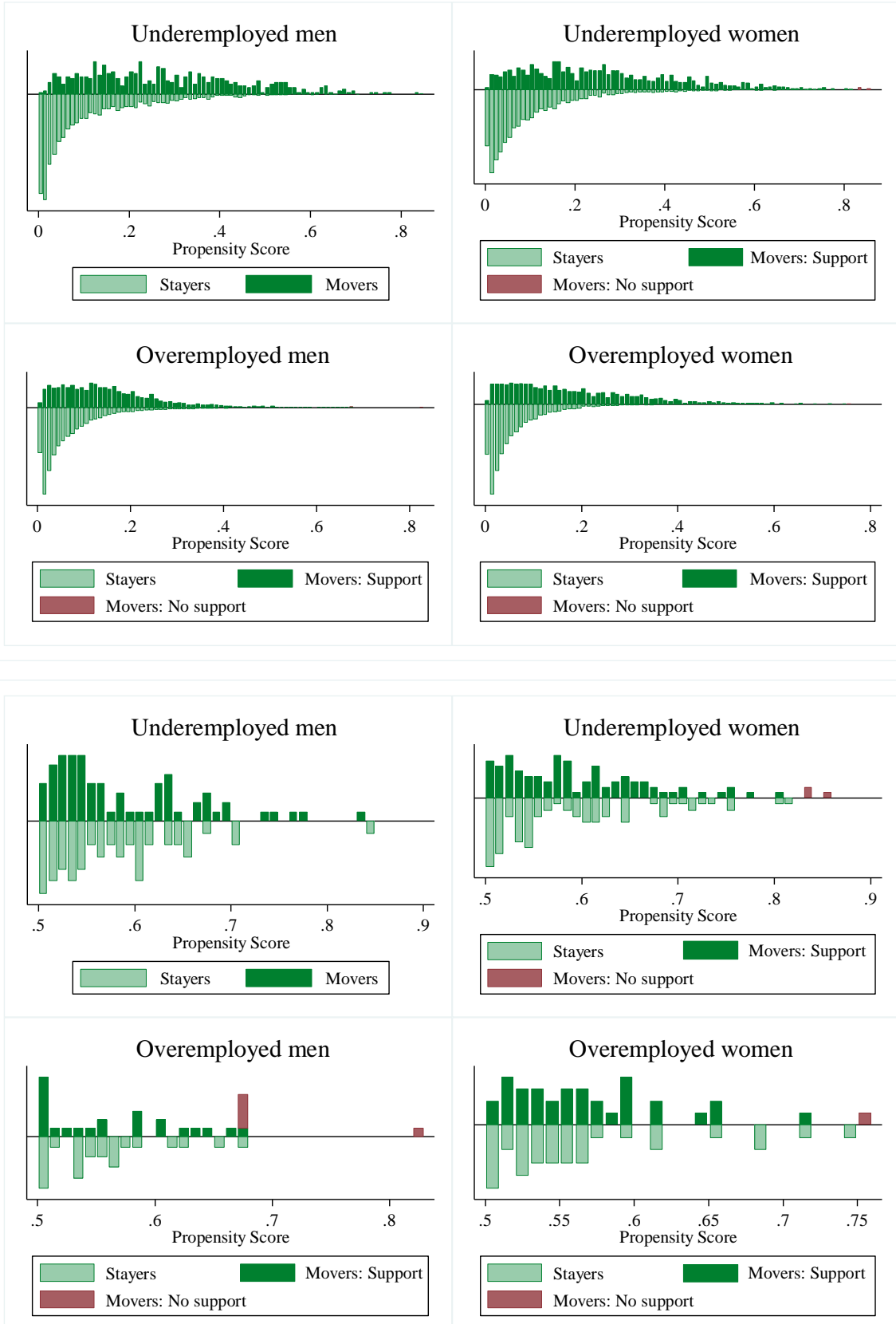

Notes: The upper panel shows the overall distribution of the propensity scores of movers and stayers 
Table D.1:Main results without observations with a propensity score $>0.6$

\begin{tabular}{|c|c|c|c|c|c|c|c|c|}
\hline \multirow[b]{2}{*}{ Underemployed } & \multicolumn{4}{|c|}{ Men } & \multicolumn{4}{|c|}{ Women } \\
\hline & Movers & Stayers & Difference & S.E. & Movers & Stayers & Difference & S.E. \\
\hline$\Delta H A_{t+1}$ & 8.010 & 3.537 & $4.473^{* * *}$ & 0.586 & 8.845 & 2.641 & $6.203^{* * *}$ & 0.492 \\
\hline$\Delta H D_{t+1}$ & -2.736 & -4.051 & $1.315^{* * *}$ & 0.505 & -0.638 & -2.332 & $1.694 * * *$ & 0.403 \\
\hline$\Delta D E V_{t+1}$ & 10.746 & 7.588 & $3.158^{* * *}$ & 0.688 & 9.483 & 4.973 & $4.509 * * *$ & 0.425 \\
\hline$O V E R_{t+1}$ & 0.336 & 0.213 & $0.123 * * *$ & 0.029 & 0.267 & 0.125 & $0.142^{* * *}$ & 0.018 \\
\hline$U_{N C O N}{ }_{t+1}$ & 0.376 & 0.380 & -0.004 & 0.030 & 0.380 & 0.269 & $0.110^{* * *}$ & 0.022 \\
\hline$U N D E R_{t+1}$ & 0.288 & 0.407 & $-0.119 * * *$ & 0.030 & 0.353 & 0.606 & $-0.253 * * *$ & 0.021 \\
\hline Observations & 497 & 3,036 & & & 877 & 6,047 & & \\
\hline Overemployed & Movers & Stayers & Difference & S.E. & Movers & Stayers & Difference & S.E. \\
\hline$\Delta H A_{t+1}$ & -2.763 & -1.313 & $-1.450 * * *$ & 0.256 & -3.519 & -1.384 & $-2.135^{* * *}$ & 0.292 \\
\hline$\Delta H D_{t+1}$ & 1.104 & 1.119 & -0.015 & 0.184 & 1.400 & 1.453 & -0.053 & 0.223 \\
\hline$\Delta D E V_{t+1}$ & -3.867 & -2.432 & $-1.435^{* * *}$ & 0.251 & -4.919 & -2.837 & $-2.083^{* * *}$ & 0.298 \\
\hline$O V E R_{t+1}$ & 0.665 & 0.746 & $-0.081 * * *$ & 0.015 & 0.581 & 0.695 & $-0.114^{* * *}$ & 0.015 \\
\hline$U_{N C O N} t_{t+1}$ & 0.271 & 0.221 & $0.051^{* * *}$ & 0.014 & 0.300 & 0.254 & $0.046^{* * *}$ & 0.015 \\
\hline$U N D E R_{t+1}$ & 0.064 & 0.033 & $0.030^{* * *}$ & 0.007 & 0.119 & 0.051 & $0.068 * * *$ & 0.010 \\
\hline Observations & 1,958 & 24,196 & & & 1,499 & 17,760 & & \\
\hline
\end{tabular}

Notes: Standard errors are based on 4999 bootstrap replications. The bootstraps are clustered on individual level. $* / * * / * * *$ indicate significance at a 10\% / 5\% / 1\% level. 